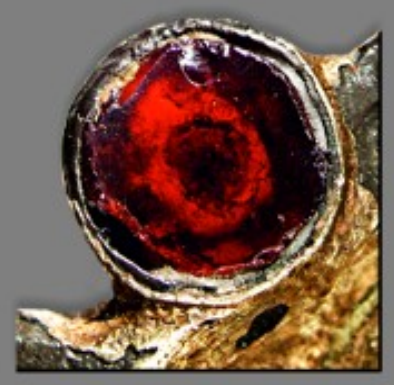

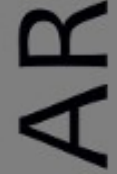

$\sim$

ш
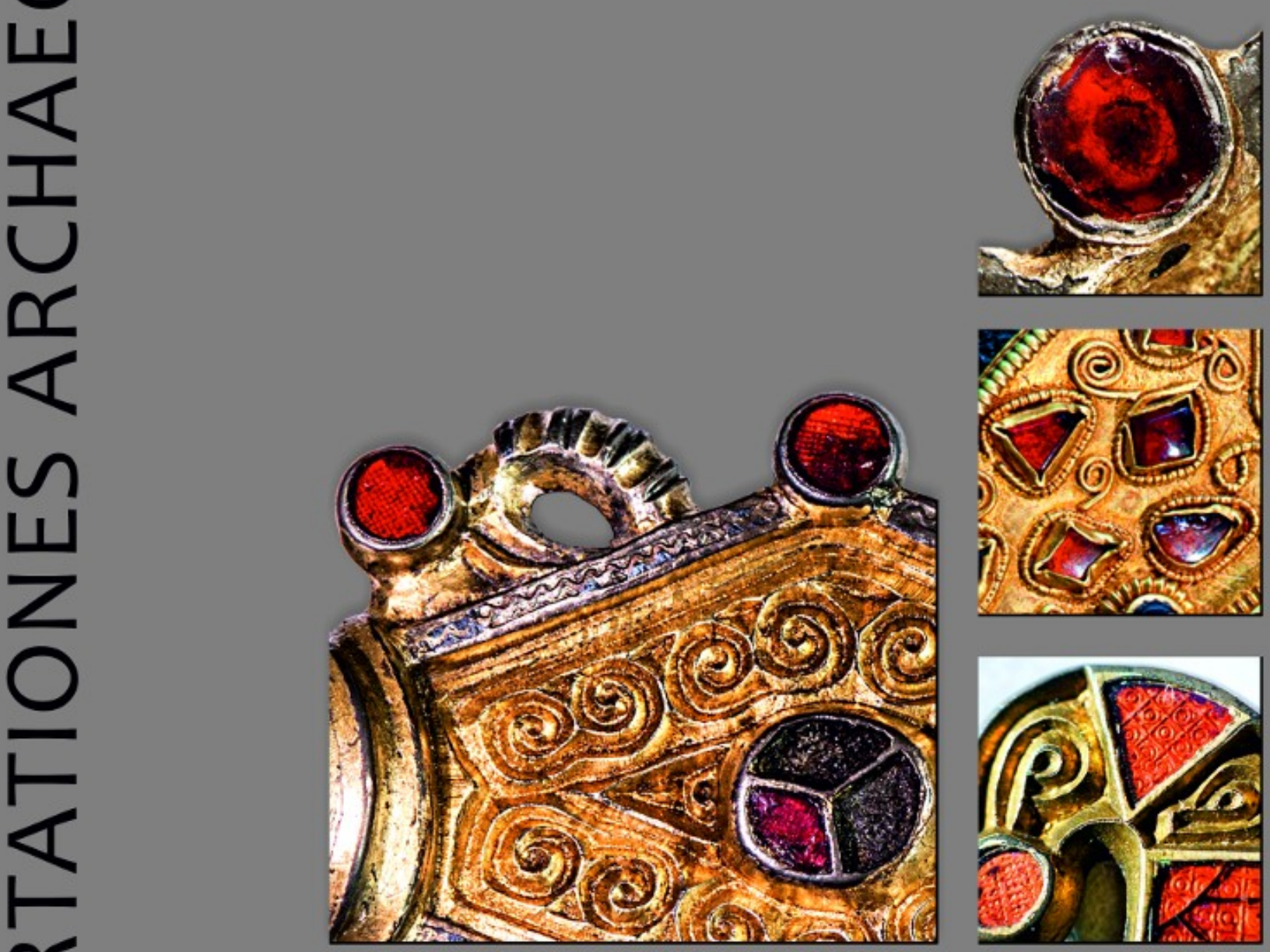

E

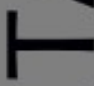

œ

山

n

ก

$\overline{0}$
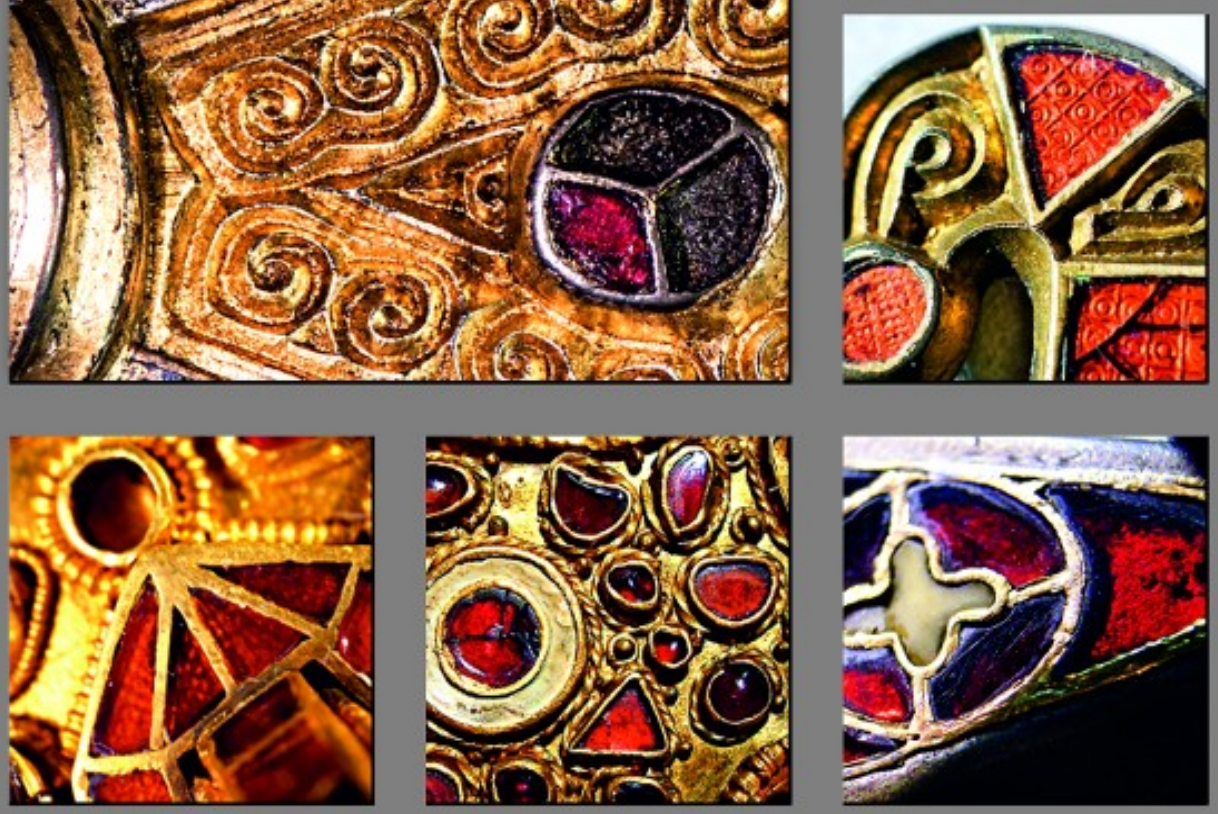

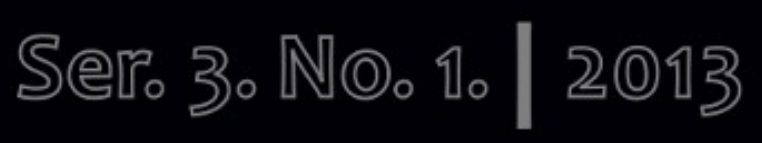




\section{Dissertationes Archaeologicae ex Instituto Archaeologico}

Universitatis de Rolando Eötvös nominatae Ser. 3. No. 1.

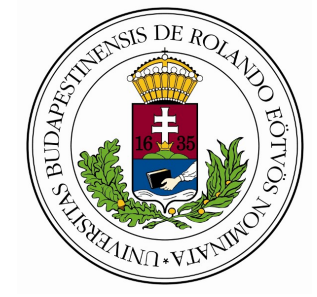

Budapest 2013 
Dissertationes Archaeologicae ex Instituto Archaeologico

Universitatis de Rolando Eötvös nominatae

Ser. 3. No. 1.

Editor-in-chief:

DÁvid BARTUS

Editorial board:

LÁSZLÓ BARTOSIEWICZ

LÁSZLÓ BORHY

ISTVÁN FELD

GÁBOR KALLA

PÁL RACZKY

Miklós SzABÓ

TIVADAR VIDA

Technical editors:

DÁvid BARTuS

GÁBOR VÁCZI

ANDRÁs BöDŐcs

Proofreading:

Zsófia KondÉ

SzILvia SzÖLlősI

Available online at http://dissarch.elte.hu

Contact: dissarch@btk.elte.hu

\section{$\underline{\text { PKP }}$ \\ PUBLIC \\ KNOWLEDGE \\ PROJECT}

(C) Eötvös Loránd University, Institute of Archaeological Sciences

Budapest 2013 


\section{Contents}

\section{Articles}

Melinda TORBÁGYI - István VIDA

The coin hoard of Abasár

Anikó BózsA

21

Roman mirrors from a private collection in the Hungarian National Museum

Lajos JuHÁsz

45

The Biesheim cameo - a reinterpretation

\section{Methods}

Péter CsIPpÁN

$A z$ állatcsont, mint információhordozó leletanyag

Kata DÉvAI

Terminológiai alapfogalmak régészeti korú üvegtárgyak elemzéséhez

Lőrinc TimáR - Zoltán Czajlik - Sándor Puszta - Balázs Holl

$3 D$ reconstructions using GPR data at the Mont Beuvray

\section{FIELD REPORTS}

Zsolt MESTER

Excavation at a new Upper Palaeolithic site of the Eger region (Northern Hungary)

László BORHY - Dávid BARTus - Emese SzÁmadó

Short report on the excavations at Brigetio (Szőny-Vásártér) in 2013

Dénes HulLÁm - Zsófia RÁcz

Report on the participation of the Eötvös Loránd University at the Wielbark Archaeological Field School in Malbork-Wielbark, Poland

Gábor VÁczi - Dávid BARTus

Short report on the excavations at the site Makó - Igási Ugar

Maxim MoRdovin

Short report on the excavations in 2013 of the Department of Hungarian Medieval and Early Modern Archaeology (Eötvös Loránd University, Budapest)

\section{THESIS ABSTRACTS}

Kitti KÖHLER

Biological reconstruction of the Late Neolithic Lengyel Culture 
Cultural connections and interactions of Eastern Transdanubia during the Urnfield period

Orsolya LÁNG

Urban problems in the civil town of Aquincum: the so-called „northern band”

Nikoletta SEY

Questions of bronze workshops in Roman Pannonia

Kata DÉvaI

Glass vessels from Late Roman times found in graves in the Hungarian part of Pannonia

Eszter HORvÁTH

Gemstone and glass inlaid fine metalwork from the Carpathian Basin:

the Hunnic and Early Merovingian Periods

Gergely SzEnTHE

Vegetal ornaments in the Late Avar decorative art

Péter LANGó

Relations between the Carpathian Basin and South East Europe during the 10th century.

The evidence of the minor objects

Ciprián HoRvÁTH

The Cemeteries and Grave Finds of Györ and Moson Counties from the Time

of the Hungarian Conquest and the Early Árpádian Age

András Sófalvi

The border- and self-defence of Szeklers from the Medieval Age till the Age of Principality.

Castles and other defence objects in the settlement history of Udvarhelyszék 


\title{
Az állatcsont, mint információhordozó leletanyag
}

\author{
PÉTER CSIPPÁN \\ Institute of Archaeological Sciences \\ Eötvös Loránd University \\ csippan79@gmail.com
}

\begin{abstract}
The aim of this paper is to rethink a special type of finds: animal bones. This kind of finds have more information than a simple biofact. And this is the first question: Is there a real category? What categories are useable for these things? The author of this paper tries to organize every type of data that are encoded in the animal bones and what is gathered during the manual identification. Using Clarke's entities of archaeological science (attribute, artefact, type, assemblage, culture, culture-group, technocomplex) we find that the animal bones are perfectly fitting in the set of things that we call: archaeological finds. For the application of these entities we have to rethink all of them for the needs of the interpretation of animal bones. Their explanation has three different facets: the taphonomical, the zoological and the cultural approaches. For understanding all encoded information we have to walk all the three ways to receive a complex and multilevel interpretation of these special types of the archaeological finds.
\end{abstract}

„Az emberi viselkedés legkézzelfoghatóbb produktuma a megmunkált tárgy - bármely olyan tárgy (objektum), amely az ember által alkalmazott attribútumokkal van ellátva.”

David L. Clarke ${ }^{1}$

\section{A régészeti lelet fogalma és az állatcsontleletek helyzete}

Az állatcsontleletek kapcsán, legelső lépésként talán érdemes megvizsgálnunk, hogy tulajdonképpen mit is nevez egyáltalán régészeti leletnek maga a régészettudomány? Melyek azok a kritériumok, amelyeknek meg kell felelnie a régészeti leletnek? Mik azok a tulajdonságok, melyek jellemeznek egy régészeti leletet?

Colin Renfrew és Paul Bahn alapvető, Régészet című összefoglalása ${ }^{2}$ - a régészeti lelet fogalmának leírása kapcsán - már a kötet elején elkülöníti a környezeti (ecofact), valamint a tárgyi leletek (artefact) csoportjait. Míg az első csoport a szerves és szervetlen környezeti maradványokat, addig a második csoport az ember által megváltoztatott és/vagy készített tárgyi emlékeket foglalja magába. ${ }^{3} \mathrm{~A}$ könyv az ásatásokon napvilágot látott állatcsontokat az első kategóriába sorolja.

Ezzel azonban már itt vitába kell szállnunk. Jóllehet maguk az állatcsontok ténylegesen és mondhatjuk elsődlegesen biológiai információkat közvetítenek a szakemberek számára, azonban a fenti egyszerüsítés figyelmen kívül hagyja az archaeozoológiai vizsgálatok legfőbb szabályát, miszerint: A lelőhelyeken feltárt állatcsontok minden esetben a korabeli emberi tevékenység megnyilvánulásai. Mindebből az következik, hogy bármit is jelent első kéz-

1 Clarke 1968, 152.

2 RENFREW - BAHN 1999.

3 RENFREW - BAHN 1999, 45. 
ből az állatcsont közvetett úton az adott kultúrára nézve legalább annyi jelentést kell hordoznia, mint bármely más leletanyagtípusnak. Az ecofact fogalmának legelső megjelenése a régészeti szakirodalomban Lewis Binfordhoz köthető, aki azonban teljesen más szinten különíti el az artefact és az ecofact fogalmát. Binford szerint:

„[ecofact] minden kulturálisan releváns, nem megmunkált /vagy nem tárgyi/ lelet.” 4

Binford szempontjait követve az állatmaradványok esetében is nyilvánvalóvá válik, hogy egy többdimenziós leletanyagtípussal állunk szemben, hiszen az előbbieket visszafordítva, nem csupán az emberi cselekvés manifesztumát jelentik, hanem - és itt mutatkozik meg a valódi különbség a többlet formájában - valamilyen szinten a korabeli társadalom, a korabeli település környezetére is reflektál.

Arra a konkrét kérdésre azonban, hogy micsoda maga a régészeti lelet nem kapunk magyarázatot, csupán megsejthetjük azt a tárgylelet (artefact) fogalmának bevezetésével, amely az összefoglaló szótár szerint:

„Minden hordozható tárgyat, amelyet ember készített, használt, ill. megváltoztatott;...” 5

A Renfrew - Bahn szerzőpáros azt is kiemeli, hogy kétségtelen a régész egyik legfontosabb feladata e tárgyleletek vizsgálata. Fontos tehát ismételten megjegyeznünk, hogy mindezen kritériumok az állatcsontleletekben is maradéktalanul megtestesülnek.

Az ásatásokon feltárt állatcsontok tehát az ember által megváltoztatott „tárgyak”, teljes értékű tárgyleletként, „az emberi viselkedés legkézzelfoghatóbb produktumaként” értelmezhetők. Amennyiben a fenti állítást axiómaként fogadjuk el, az állatcsontleletekre a régészet által megfogalmazott, a tárgyleletekre vonatkozó fogalmak, jellemzők és törvényszerűségek feltétel nélkül érvényesek.

David L. Clarke összefoglaló, Analytical Archaeology címü munkájában a tárgyleleteket olyan jelenségrendszer részének tekinti, amelyet az általa a régészeti kutatás entitásainak nevezett több, egymással hierarchikus kapcsolatban álló megjelenési, vagy értelmezési szint alkot: ${ }^{6}$

- az attribútum (attribute)

- a tárgy (artefact)

- a tárgytípus (type)

- a leletegyüttes (assemblage)

- a kultúra (culture)

- a kulturális csoport (culture group)

- a technológiai komplexum (technocomplex)

Clarke szerint minden egyes entitás alacsonyabb szintű komponensekből áll, amelyek mikrorendszerként müködnek együtt a szociokulturális rendszer egy-egy hozzájuk szorosan kapcsolódó részével. ${ }^{7}$

4 Binford 1964, 432.

5 RENFREW - BAHN 1999, 550.

6 CLARKe 1968, 206.

7 Clarke 1968, 150. Clarke a kultúra rendszeréről és annak alrendszereiről alkotott elképzeléseit a későbbiekben részletesen tárgyalom. 


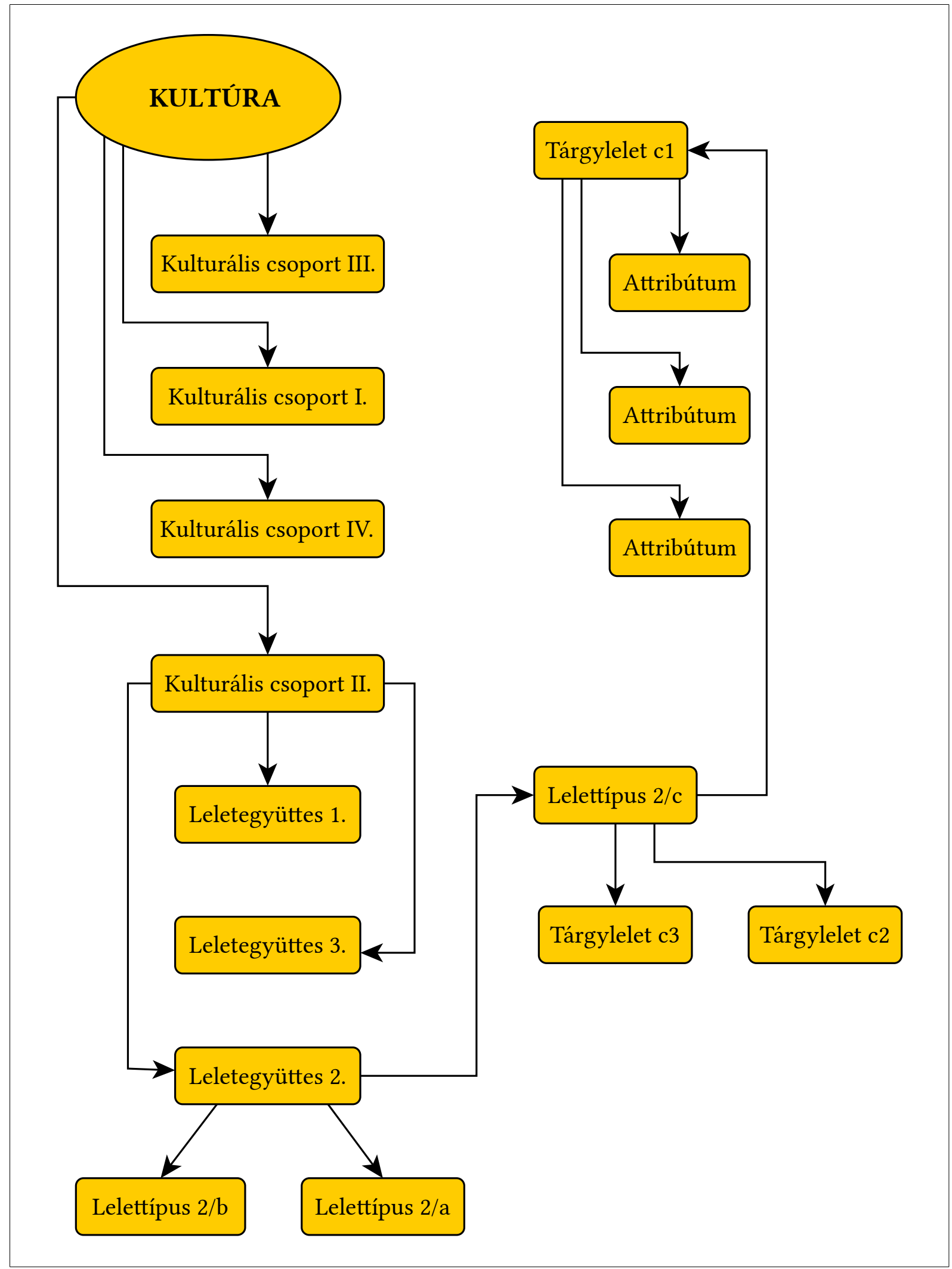

Fig. 1. A régészeti entitások kapcsolatrendszere. System of the archaeological entities. 
Nyilvánvaló, hogy bár a fenti kategóriák mind nagyságukat, mind minőségüket tekintve eltérőek, a közöttük lévő kapcsolat alapvetően szabályosságot mutat. ${ }^{8}$ A sorrend egyben a komplexitás szintjét is kifejezi, így az entitások legalacsonyabb szintjei az attribútum, majd a tárgylelet. ${ }^{9}$

Az attribútum olyan minőség, amely az egyes tárgyakat első szinten meghatározza. Magába foglalhatja a tárgy anyagát, színét, formáját, valamint díszítés- és motívumkincsét is. ${ }^{10}$ Ugyanakkor attribútumként értelmezhető az adott tárgy előkerülési vagy használati kontextusa, funkciója (sírkerámia, házikerámia, stb.) is. Az attribútum Clarke szerint olyan logikai, tovább nem egyszerűsíthető jellemző, amely független változóként meghatározza a tárgyrendszerek bizonyos állapotait. ${ }^{11}$ Episztemológiailag független változó. Az attribútumok három típusát különíthetjük el: ${ }^{12}$

- nélkülözhető (inessential): kevéssé jelentősek, általában konstansnak tekinthetőek, nem befolyásolják a változók rendszerét.

- nélkülözhetetlen (essential): ezek a változók egy releváns rendszer részének tekinthetőek, változásuk a releváns változórendszer átalakulását eredményezi. Ezek elemzése jelöli ki a kulcs attribútumokat.

- kulcs (key): különböző változócsoportokkal állnak kapcsolatban, a változó rendszer értékeit vagy állapotát befolyásolhatják.

A tárgylelet összefoglaló fogalom. Magába foglal méretétől függetlenül minden olyan objektumot, amely emberi kéz által alkotott attribútumokkal vagy attribútum szettekkel van ellátva: ${ }^{13}$

„Minden tárgy, tehát minden kézzel fogható objektum a változók (attribútumok) végtelenjét tartalmazza, így egy a változók (attribútumok) által alkotott hálózattal rendelkezik." 14

A tárgyleletek értelmezéséhez az Új Régészet olyan csoportokat, vagy osztályokat alkotott, amelyek képesek voltak összekapcsolni a rendszerszemléletű gondolkodást az előkerülő leletekkel, ezáltal közelítve az elméleti és gyakorlati régészeti módszereket. Binford 1962-ben megjelent írásában, melyet a processzuális régészet zászlóshajójának nevezhetünk, a következő tárgyosztályokat vezeti be ${ }^{15}$

- techno-ökonómiai (technomic): ezen csoportba tartozó tárgyak olyan jellegzetességekkel bírnak, melyek alapján funkcionalitásuk anyagi környezetükkel hozható öszszefüggésbe.

- szocio-technológiai (socio-technic): a csoport tagjai olyan tárgyak, melyek anyaga és funkciója a kulturális rendszer társadalmi alrendszerére reflektál. Ezeknek a tárgyaknak a változása az általuk reprezentált szociokulturális rendszer természetének, vagy struktúrájának változására mutat rá.

8 Clarke 1968, 151.

9 Clarke 1968, 151.

10 GAMBLE 2004, 55.

11 Clarke 1968, 206.

12 Clarke 1968, 155

13 Clarke 1968, 206.

14 Ashby 1972, 53, idézi Clarke 1968, 155.

15 BINFORD 1962, 219. 
- ideo-technológiai (ideo-technic): ebbe a csoportba olyan tárgyak tartoznak, amelyek a társadalmi rendszer ideológiai részével vannak kapcsolatban. Sajátos ideológiai képzeteket szimbolizálnak, ezáltal nyerve funkcionalitást az adott népesség szociológiai rendszerében.

E fogalmak Clive Gamble könyvében írt kritikája azonban felhívja a figyelmet arra, hogy a tényleges tárgyak sok esetben, sőt majdnem minden esetben részei mindhárom csoportnak. ${ }^{16}$ Ebből következik, hogy a binfordi csoportok sokkal átjárhatóbbak, mintsem ténylegesen analitikai osztályokat alkossanak. Az állatcsontleletek esetében a binfordi csoportok alkalmazása azonban célravezető lehet, hiszen e lelettípus értelmezését csakis a fenti osztályok mentén kísérelhetjük meg, jóllehet nem tényleges csoportok kialakításával, hanem azok analitikai síkként való alkalmazásával.

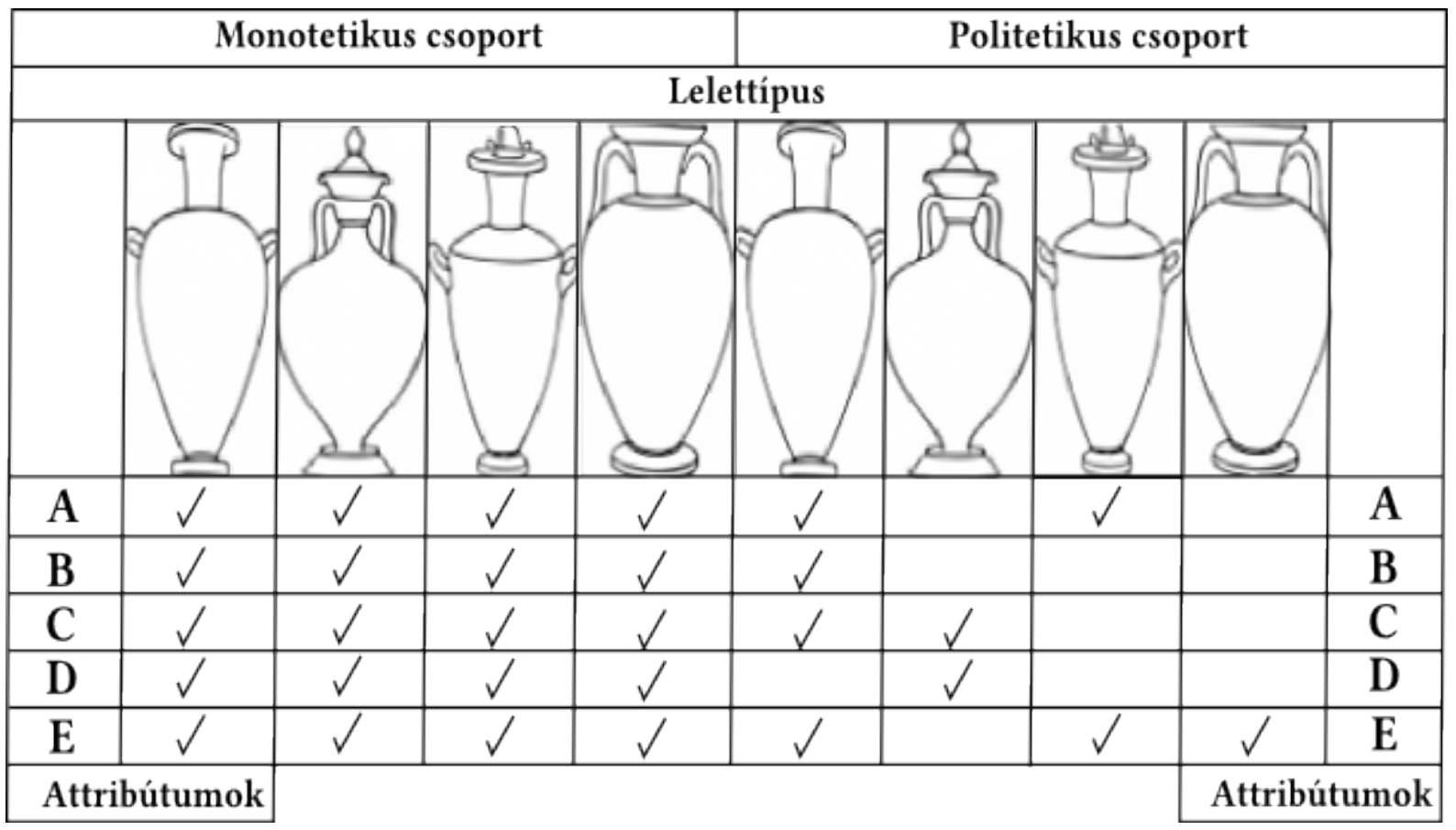

Fig. 2. A monotetikus és a politetikus tárgytípusok és leletcsoportok osztályozási rendszere. Monothetic and polythetic systems of classification (after GAMBLE 2004).

A tárgy és az attribútum által meghatározott egységet nevezzük tárgytípusnak. A régészeti entitások kapcsolatrendszere Clarke szerint egy tárgytípus egyfajta koncentrált, kézzelfogható eredménye azoknak a cselekvés folyamat(ok)nak, illetve viselkedési szükségletnek, amelyeket az adott tárgytípushoz kötődő absztrakciók tartalmaznak, vagy még inkább megkövetelnek a készítő elméjében, vagy sokkal inkább világképében. ${ }^{17}$ Ennek következtében minden tárgy eredendően magába foglalja a készítéséhez, valamint a használatához köthető cselekedetek összességét, állítja Clarke. ${ }^{18}$ A tárgy tehát elkészítése pillanatától kezdve több síkon kódolt információkat tartalmaz, amelyek teljes feloldásához a közösség a tárggyal öszszefüggésbe hozható teljes kozmológiai tudására van szükség (Fig. 1). 
Önálló entitás a tárgytípus, amely sajátos attribútumokkal rendelkező régészeti tárgyakból áll. Egészen pontosan ezek a tárgyak az azonos szintű attribútumok vagy attribútum készletek által alkotott politetikus csoportot képeznek. Clarke a tárgytípusnak különböző szintjeit állapította meg. Ezek a következőek: ${ }^{19}$

- típus-csoport: egymáshoz szorosan kapcsolódó, vagy egymást kiegészítő tárgytípusok, valamely közös komponens, vagy attribútum-készlettel rendelkeznek, amely(ek) szabályozzák és előírják a tárgytípus alapanyagát és/vagy felhasználási területét.

- típus: speciális tárgytípus. A tárgyak azon homogén populációja, amely konzekvensen ismétlődő attribútumcsoportok által politetikus csoportokat alkot.

- altípus: egy speciális tárgytípus homogén altípusa vagy variációja.

Mivel az egyes tárgytípusok az őket meghatározó attribútumok által írhatók le, így a tárgyleletek és az azokat meghatározó attribútumok azonosságaik vagy különbözőségük alapján képezhetnek monotetikus vagy politetikus leletcsoportokat (Fig. 2) ${ }^{20}$ A régészeti gyakorlatban természetesen ez utóbbi leletcsoportok nevezhetők általánosnak. A leletcsoport tehát az azonos korú, egymással kapcsolatban álló tárgytípusok összességét jelenti. ${ }^{21}$

Az ötödik, a fentieket összefoglaló és bizonyos értelemben a többit meghatározó, azok felett álló entitás: a kultúra. Ennél a pontnál azonban rögtön különbséget kell tennünk kultúra és kultúra között. A kultúra szó alatt ugyanis mást értenek a régészettudományban, mint a rokon kulturális antropológia tudományának területén. Bár Clarke minden bizonnyal régészeti kultúrát ért a „kultúra” szó alatt, pusztán a régészeti kultúra jelenségét nem feleltethetjük meg tényleges etnikumoknak. Mint azt kifejti, az anyagi kultúra megjelenési területei és más jelentős kulturális jelenségek, mint a nyelv - recens ethnoarchaeológiai példák alapján - földrajzi elterjedései nem esnek feltétlenül egybe. ${ }^{22}$

A régészeti kultúra pontos fogalmát igazán annak kialakulásán keresztül érthetjük meg. $\mathrm{E}$ fogalom, egyáltalán az őskori népességek kulturális elkülönítését elsőként az osztrák Gustav Kossina kisérelte meg. Kossina a késő antik és középkori írott források alapján próbálta meghatározni az őskori kulturális egységeket, vagy ahogyan ő fogalmazott: kultúrprovinciákat. ${ }^{23}$

„A szigorúan körvonalazott, élesen elkülönülő, zárt régészeti kultúrprovinciák feltétlenül egybeesnek bizonyos nép- vagy törzsterületekkel." ${ }^{24}$

Az elmélet, annak igen jelentős megállapítása ellenére - miszerint a régészeti kultúra és a korabeli népesség egymásnak megfeleltethető - egy alapvető problémát nem vesz kellőképpen figyelembe. Ez pedig a kultúra változásának jelensége. Kossina az emberi kultúrát bizonyos értelemben állandónak, illetve annak egyes elemeit konstansnak tekintette. ${ }^{25}$ Így lehetséges az, hogy a kulturális változásnak, vagy még inkább a kultúrák közötti kapcsolatok egymást átformáló hatásának nem tulajdonított szerepet. Kossina szerint az, hogy egy kultúra teljesen átalakuljon, kizárható. ${ }^{26}$

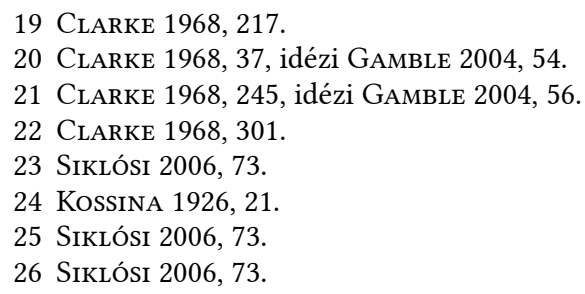


A régészeti kultúra mai napig használatos fogalmának megalkotója - az írásaiban a marxista gazdasági alapokat képviselő - Vere Gordon Childe volt. Childe már nem csupán a történeti források alapján, hanem a tényleges régészeti leletek és az ásatásokon feltárt régészeti jelenségek szabályosságai alapján igyekezett kialakítani a korabeli népcsoportokkal való megfeleltetés lehetőségét:

„Bizonyos emléktípusok - edények, eszközök, temetkezési rítusok, házformák - állandóan együtt kerülnek elö. Az ilyen szabályosan összetartozó vonások összességét kulturális csoportnak, vagy egyszerúen kultúrának hívjuk. Feltételezzük, hogy az ilyen komplexumok annak a tárgyi kifejeződései, amit ma népnek hívnánk.” 27

Az Új Régészet beköszöntével a kultúra fogalma a régészettudományban jelentősen megváltozott. Binford 1962-ben írt tanulmányában már erőteljesen hangsúlyozza a kultúra rendszerszemléletű jellegét. ${ }^{28}$ Értelmezését jelentősen áthatja Leslie A. White az emberi kultúráról alkotott evolucionista elképzelése:

„A kultúra a környezethez való alkalmazkodás (adaptáció) eszközének tekinthetô. ${ }^{29}$

Később Binford kissé kiegészíti a kultúráról alkotott fogalmát, bár továbbra is hangsúlyozza annak adaptív tulajdonságát és extraszomatikus (testen kívüli) jellegét:

„A kultúrát egy hatalmas áramló folyamnak tekinthetjük kisebb variációkkal a fogalomalkotási normákban, ami az edénykészítés, házasságkötés stb. helyes módját illeti. [...] Ezek a fogalomalkotási különbségek időről időre térben és időben különböző pontokon kristályosodnak ki, különálló és néha feltūnő kulturális tetőpontokat eredményezve, ami lehetővé teszi számunkra, hogy a kultúra folytonosságát kulturális fázisokra bontsuk." ${ }^{30}$

A kibernetikai folyamatokban gondolkodó Clarke kultúra-elmélete híven tükrözte a rendszerelméleti megközelítést:

„A szociokulturális rendszer egy olyan egységrendszer, melyben minden kulturális információ az egymással érintkezésben álló attribútumok stabil, de állandóan változó hálózata, mely egy komplex egészet, dinamikus rendszert alkot." 31

Amennyiben pusztán az anyagi kultúra oldaláról tekintjük a definíciót Clarke kínál egy kultúrafogalmat ehhez a nézőponthoz is:

„A speciális és széles körben értelmezett típus-kategóriák politetikus készlete, amely kategóriák a leletcsoportok szintjén ismétlődően megegyeznek egy földrajzilag behatárolt területen.” 32

Szerinte a kultúra három egymásnak alárendelt szinten különíthető el:

- kulturális csoport

- kultúra

- szubkultúra

27 CHILDE 1929, v-vi.

28 BINFORD 1962.

29 BINFORD 1962, 215.

30 BINFORD 1965, 204.

31 Clarke 1968, 42.

32 Clarke 1968, 206. 
A fenti szintek kissé ellentmondásban, vagy átfedésben állnak a clarke-i értelemben vett entitásokkal. Ezt az ellentmondást azonban Clarke nem oldotta fel (Fig. 3).

Fontos megjegyezni azt is, hogy bár Clarke minden bizonnyal régészeti kultúrát ért a „kultúra” szó alatt, pusztán a régészeti kultúra jelenségét nem feleltethetjük meg tényleges etniku moknak. Mint azt - recens ethnoarchaeológiai példák alapján - kifejti, az anyagi kultúra megjelenési területei és más olyan jelentős kulturális jelenségek, mint például a nyelv, földrajzi elterjedései nem esnek feltétlenül egybe. ${ }^{33}$ Ezzel kritikát fogalmaz meg a Childe-féle kultúrafogalommal szemben.

Binford és Clarke kultúraszemléleteit a későbbiekben számos kritika érte. A legtámadhatóbb pontnak a kultúra túlzott funkcionalista értelmezése, illetve az „általános szabályok” túlzott általánossága mutatkozott. ${ }^{34}$

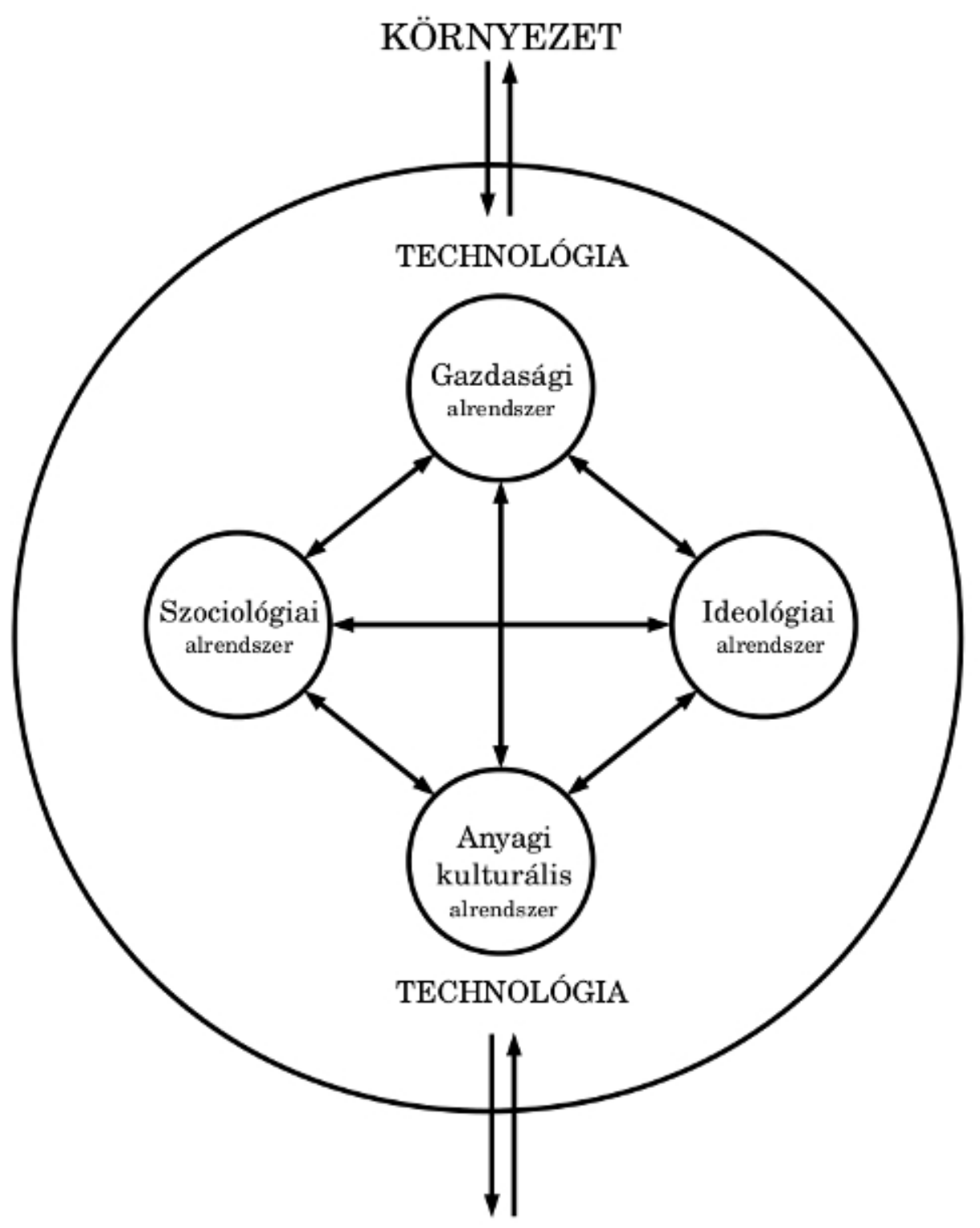

Fig. 3. A kultúra statikus modellje. Static model of the culture (after ClARKE 1968). 
Az Új Régészet kritikája a régészeti kultúra fogalmának változását is magával hozta. A posztprocesszualista iskola képviselői sokkal nagyobb hangsúlyt helyeztek az egyén és a társadalmi ideológia szerepére. ${ }^{35}$ Magát a régészeti kultúra fogalmát elvetették, mert szerintük ezt sem a társadalmi identitás kifejezőeszközeként, sem pedig tényleges régészeti entitásként nem lehet értelmezni. A régészeti kultúra fogalmának kategorikus elkerülését, a tudományos szaknyelvből való kivezetését gondolták célravezetőnek. ${ }^{36}$

A posztprocesszualista irányzat egyik vezéralakja Ian Hodder ethnoarchaeológiai példák alapján arra a következtetésre jutott, hogy az anyagi kultúra szerepe az adott társadalmak életében lényegesen sokrétűbb, mint azt korábban feltételezték. Az adott tárgyak önálló jelentéssel bírhatnak, amely az adott kontextustól függ. Így lehetséges az, hogy egyes esetekben tükrözhet etnikai identitást, máskor azonban nem. ${ }^{37} \mathrm{~A}$ kognitív régészeti irányzatokban sokkal jelentősebb szerepet kap a stílus, mint az identitás kifejezésének eszköze, illetve az egyes tárgyleletek életciklusának vizsgálata. ${ }^{38}$

Martin Furholt felhívta a figyelmet arra, hogy míg a régészeti kultúra jellegét tekintve monotetikus, ${ }^{39}$ addig az emberi kultúra ezzel szemben politetikus jellegű. Ezáltal a régészeti kultúra nem képezheti le önmagában a tényleges emberi kultúrát. ${ }^{40}$

A fentiek alapján világossá válik, hogy a régészeti kultúra fogalma nem bár értelmezhető önálló entitásként, hiszen pusztán fenomenológiai kategória, teljes elvetése problematikus lehet. Amennyiben tehát el is fogadjuk, hogy a régészeti kultúra fogalma elavulttá vált és használata szükös keretek között tartja a kutatást, analitikai egységként való újraértelmezése új, a korábbi eredményeket könnyedebben átemelő kutatási eszközzé válhat.

A régészet integratív tudomány, így nem szabad megfeledkeznünk arról, hogy a kultúra fogalmának integrálása alapvetően a néprajz és a kulturális antropológia tudományának területéről ered. Az etnológiában használatos kultúra fogalom kialakulása és változása tehát jelentősen befolyásolta a régészet emberi társadalmakról alkotott elméleteit. Mindezek miatt szükséges az antropológiai értelemben vett kultúra fogalmának vázlatos tisztázása is.

A kultúra fogalmának egyik első összefogott meghatározását Edward Burnett Tylor brit antropológus tette közzé. Tylor a következőképp határozta meg a kultúrát a Primitive Culture című 1871-ben megjelent monumentális munkájában:

„[A kultúra] az a komplex egész, amely magában foglalja a tudást, a hitet, a müvészetet, az erkölcsöt, a törvényt, a szokást és minden olyan emberi képességet és habitust, melyet az ember a társadalom tagjaként elsajátít." ${ }^{41}$

Tylor definíciója kiválóan mutat rá a társadalmak, a kultúra rendkívüli összetettségére, ám ezzel meg is alkotja e túlzott komplexitás összes nehézségét. Tylor óta a kultúra fogalmát újra és újra alakították a vele foglalkozó antropológiai iskolák és az antropológusok. Ezáltal maga a kultúra fogalma is tipologizálható „kulturális jelenséggé” vált; léteznek leíró, történeti, normatív, strukturális, pszichológiai, rendszerelméleti és szemiotikai definíciók. Az alábbi példák, a teljesség igénye nélkül, híven tükrözik a kultúra fogalmának a sokszínűségét.

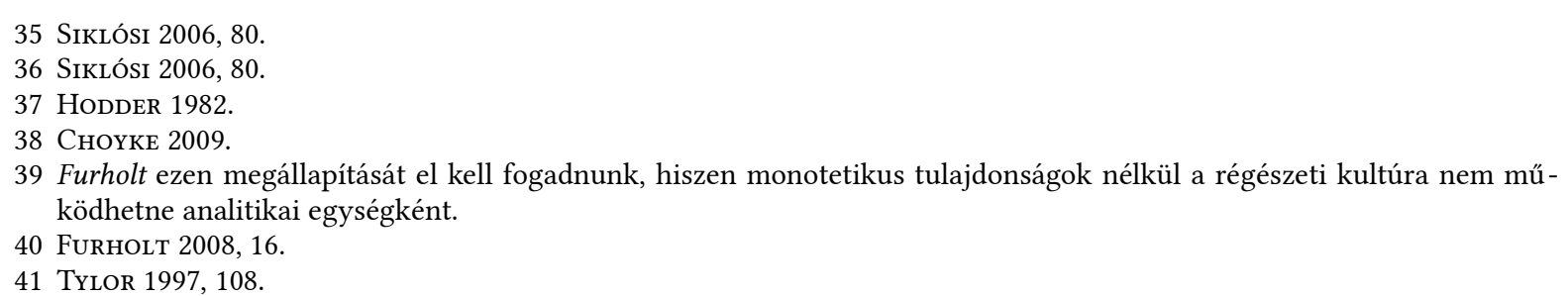


A leíró csoportba sorolható Franz Boas definíciója, amely felsorolja a kultúra egyes elemeit, ugyanakkor hangsúlyozza a kultúra közösségi jellegét:

„A kultúrát úgy határozhatjuk meg, mint azoknak a szellemi és fizikai reakcióknak és tetteknek az összességét, amelyek egy társadalmi csoport egyedeinek kollektív és egyéni magatartását jellemzik.” 42

Míg a leíró meghatározásokkal szemben eltérő megközelítést nyújt a kultúrát funkcionális folyamatként értelmező Radcliffe-Brown, aki szerint:

„[a kultúra] az a folyamat, melynek során az egyén tudásra, jártasságra gondolatokra, hitre, izlésre, érzelmekre tesz szert más személyekkel vagy tárgyakkal való kapcsolataiban." 43

Clifford Geertz kultúrafogalma magyarázó, szemiotikai jellegü. Geertz szerint, a kultúra egy jelentésekkel teli világ. Egy elvonatkoztatott, a szokások és viselkedések összessége által alkotott rendszer. Geertz úgy fogalmaz, hogy:

„[a kultúra értelmezheto szimbólumok] egymásba nyúló rendszereinek összessége, a kultúra nem valamiféle erő, amelyet a társadalmi események viselkedések, intézmények vagy folyamatok okának tarthatunk; kontextus, amelyen belül valami érthetöen - azaz sürün - írható le." ${ }^{4}$

Mint a fentiekből is kiderült a kultúra fogalma igen képlékeny. Folyamatosan alakul, a korszellem és a tudomány változásának tükrében. Néhány alapvetés azonban minden kultúra definícióban közös: ${ }^{45}$

- a kultúra tanult.

- a kultúra közös, a közösség minden tagja osztozik benne.

- szimbólumokon alapszik (pl. a beszéd).

- a kultúra integrált, minden része együttmüködik.

A régészettudományban egy többé-kevésbé a kultúra felett álló entitás a kulturális csoport. A kulturális csoport definíciója szerint az egymással rokonítható kultúrákat foglalja magába:

„Egymással rokonságban álló, járulékos kultúrák csoportja, melyek az adott speciális többszintú tárgytípusok közös, ám eltérő szintû, politetikus leletcsoportjain osztoznak." 46

A kulturális csoport tehát alapvetően egymással szoros kapcsolatban lévő kultúrák csoportja. Ezen kapcsolat a kiterjedt kulturális tradíciók egyfajta szubkulturális leképeződése. ${ }^{47}$

Végül a mindezek felett álló, ám tulajdonképpen összefüggéseit tekintve sokkal lazább entitás: a technológiai komplexum. A technológiai komplexum fogalma nem más, mint a kulturális csoport jelenségének kiegészítése, vagy még inkább kiterjesztése:

42 BoAs 1975, 63.

43 Descola et Al. 1994, 131.

44 GeERTZ 2001, 206.

45 Hollós 2000, 27.

46 Clarke 1968, 300.

47 Clarke 1968, 300. 
„Egymással rokonságban álló, járulékos kultúrák csoportja, melyek az adott speciális többszintü tárgytípusok közös, ám eltérő szintû, politetikus leletcsoportjain, valamint rendkívül széleskörü és egymással összefüggésben lévő - a környezet, a gazdaság és a technológiai tényezőkre adott - kulturális válaszokon osztoznak.” ${ }^{8}$

A Clarke által alkotott két utolsó entitásfogalom, vagy inkább analitikai kategória több helyen mosódik össze a kulturális antropológia diffuzionista iskoláinak kulturális area, vagy kultúrkör elméleteivel. Talán ezzel is magyarázható, hogy Clarke a leglényegibb különbséget a kultúra, a kulturális csoport és a technológiai komplexum között azok méretében látja. ${ }^{49}$

A kulturális area (culture area) elméletének kidolgozója Clarke Wissler volt, aki antropológusként az egyes kultúrák közötti azonosságokra építette elméletét. Szerinte a műveltség térbeli elterjedése alapján kulturális areákat állapíthatunk meg, amelyek körülhatárolásához az emberi tevékenység alapjául szolgáló jelenségeket kell figyelembe venni (pl.: élelemszerzés). Ezek a tevékenységek a mindennapi életet is meghatározzák. Az így megállapított kulturális areáknak vannak központi és marginális területeik és centrumaikban összpontosulnak mindazok az elemek, amelyek alapján kulturális areákról beszélhetünk. Wissler szerint az egyes kulturális areákban a magasabb rendű tevékenységek helye mindig a központi részben található, így a marginális területek megőrzik az archaikus elemeket. ${ }^{50}$

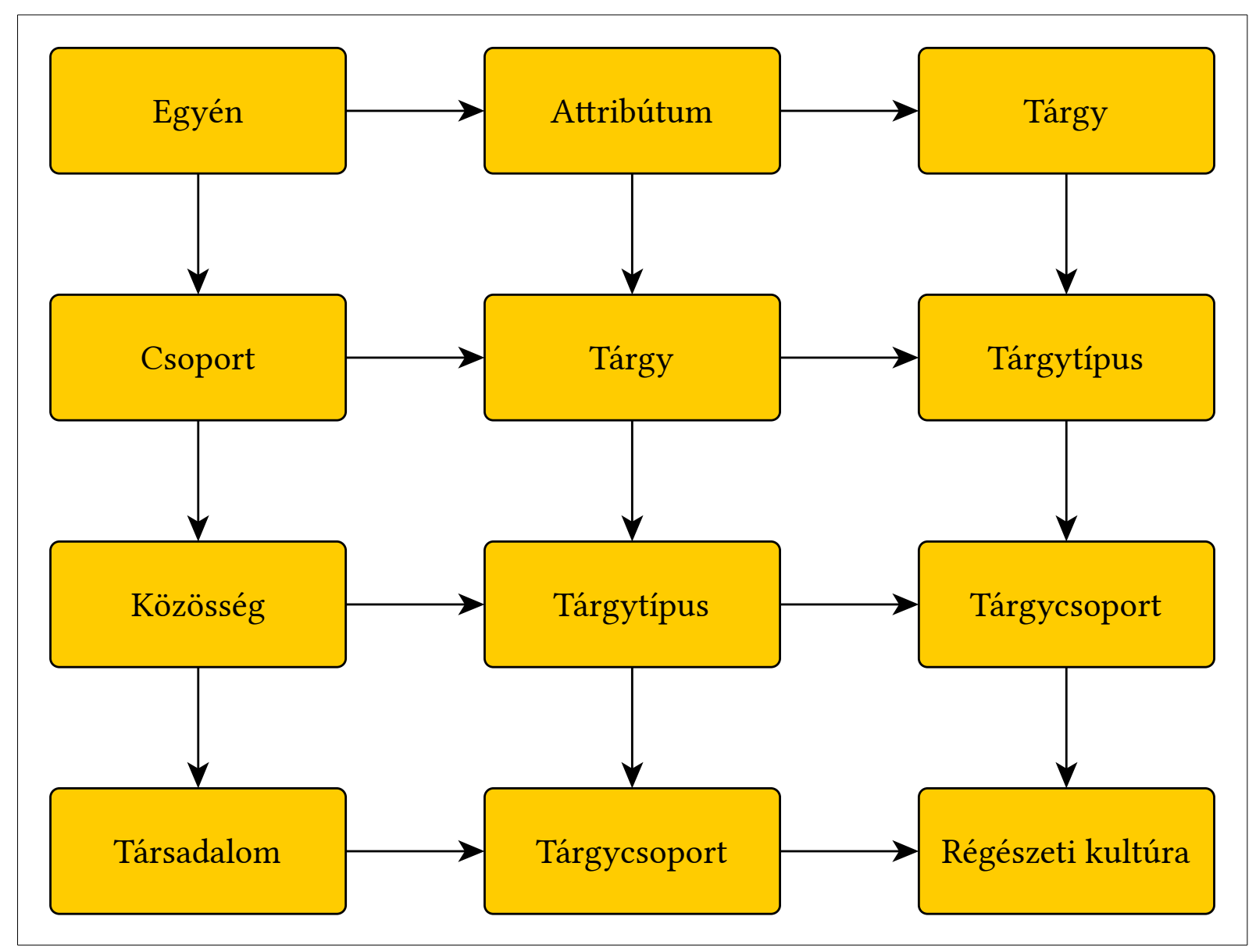

Fig. 4. A régészet entitásai és társadalmi megfeleltetésük. Archeological entities (after Clarke 1968). 
A kultúrkörök elmélete ezzel szemben a német diffuzionista iskolához köthető. A geográfus és zoológus Friedrich Ratzel és tanítványa a kultúrmorfológus Leo Frobenius álláspontja szerint, az emberi kultúra történetében csak egyszer került sor valaminek a feltalálására, és az egyszer feltalált „kultúrelemek” azután kölcsönhatások vagy népcsoportok tényleges migrációja révén terjedtek el. A kultúrkörök lényegében kultúrelemek alkotta, nagy területeken elterjedt kultúra-komplexumok, amelyek szórt, foltszerü előfordulásai egymáshoz hasonlóak lehetnek, ezáltal genetikusan összefüggenek. Frobenius felfigyelt arra, hogy nemcsak egyes kultúrelemek között vannak hasonlóságok, hanem egész kultúra-komplexumok, sőt egész kultúrkörök között is, így tehát a kulturális hasonlóságokat nemcsak az egyes elemek, hanem teljes kultúrkörök vándorlásával lehet magyarázni. ${ }^{51}$

A Clarke által leírt, egymásból felépülő entitások megállapításával, a korábbi, művészettörténeti megközelítésekhez képest teljesen új szempontokat vezetett be a régészet leleteket osztályozó módszereibe. ${ }^{52}$ Mint azt a jelen alfejezet elején említettem, Clarke elképzelése alapján az egyes régészeti entitások a társadalomszerveződési szintek adott egységeinek feleltethetők meg. Az entitások tulajdonképpen az analitikus régészeti leletelemzés első lépései testesítik meg. Az entitások felismerése és kutatása teszi lehetővé, hogy a régészet alapvető kérdéseire válaszokat kereshessünk, hiszen az entitások mentén vállnak meghatározhatóvá, felismerhetővé és csoportosíthatóvá az egyes leletek (Fig. 4).

Az alábbiakban - minden kritikai megfontolást figyelembe véve - megpróbálom az itt ismertetett alapkategóriák használatát az állatcsontleletek tekintetében. Jóllehet a kérdés nagyon szűk keresztmetszetét igyekeztem felvázolni. Az áttekintés korántsem teljes, hiszen egy önálló tanulmány témája lehetne. A teljesség igényétől tehát ez esetben el kell tekintenünk, ám célkitűzésünk itt nem is lehetett több, mint az elméleti alapok áttekintése, ami nélkül azonban az állatcsontleletek értelmezési lehetőségeivel érdemben nem foglalkozhatnánk.

\section{A leletképződés folyamata: Tafonómia}

Miután vázlatosan tisztáztuk a régészeti lelet és a hozzá kapcsolódó alapvető entitások fogalmait, fontos beszélnünk azokról a tényezőkről és folyamatokról, melyek létrehozzák ezeket a leleteket, befolyásolják állapotukat és mennyiségüket. E folyamatoknak kiemelt szerepük van az állatcsontleletek esetében, hiszen azok megtartását, megőrződését sokkal inkább befolyásolják az alábbi folyamatok. Az alábbi folyamatok lényege azonban egyéb lelettípusok esetében is azonos.

Mint eszköztárából oly sok mindent, a régészet tudománya a leletek „képződésének” folyamatát, illetve annak értelmezését természettudományos területről, a paleontológiától kölcsönözte. A paleontológia egy speciális ága, részterülete foglalkozik az őslénytani „leletek”, a fosszíliák kialakulásával. Ez a részterület: a tafonómia. A tafonómia tudományának megalkotója Ivan A. Jefremov ${ }^{53}$ szovjet paleontológus volt, aki 1940-ben megjelent Taphonomy: a new branch of paleonthology című munkájában fektette le az általa alkotott új tudományág módszertani alapjait. ${ }^{54}$ Jefremov az új résztudomány nevét a $\tau \dot{\alpha} \varphi \circ \varsigma=$ sír és a vo $\mu$ ó $\varsigma$ tör vény ógörög szavakból alkotta meg, utalva ezzel annak célkitűzésére, miszerint a tafonómia

51 VAJDA $1949,46$.

52 GAMBLE 2004, 54.

53 fefremov nem mellékesen kiemelkedő science-fiction szerző is volt. Olyan művei, mint az Androméda-köd vagy A borotva éle a science-fiction irodalom klasszikusainak számítanak.

54 JEFREMOV 1940. 
az eltemetődés, vagy beágyazódás tudománya. ${ }^{55}$ Jefremov elkülöníti a recens fauna tafonómiai vizsgálatával foglalkozó actuotafonómiát, valamint az őskori állatvilággal foglalkozó paleotafonómiát. Ebből egyértelművé válik, hogy a tafonómiai vizsgálatok ún. aktualisztikus megközelítést alkalmaznak, melyek feltételezik, hogy a régmúltban lejátszódó folyamatok minősége és hatásai azonosak lehettek a mai hasonló folyamatokkal.

Természettudományos értelemben a tafonómia, mint segédtudomány, azoknak a folyamatoknak az összességével foglalkozik, amelyek az elhullott egyedek halálával kezdődően - legyen az földtörténeti kor, vagy recens időszak -, annak végleges beágyazódásán keresztül, a jelenkori állapotig tartanak. ${ }^{56}$ Alapvetően két nagyobb részre oszlik: ${ }^{57}$

- biosztratinómia

- fosszilis diagenézis

A biosztratinómiai vizsgálatok fókuszában a szervezet elhalásától, annak végleges beágyazódásáig bekövetkezett folyamatokat állnak. ${ }^{58}$ Lépésenként vizsgáljuk a szerves anyag lebomlásának folyamatát, a csontos váz sorsát, esetleges szétesését, majd a tényleges beágyazódását. Ez a részfolyamat alapvetően kétféle úton mehet végbe: ${ }^{59}$

- autochton beágyazódás

- allochton beágyazódás

Míg az első esetben a beágyazódás folyamata az elhalás helyén megy végbe, addig az allochton beágyazódás esetében az elhalás és a betemetődés folyamata között szállítódás (transzportáció) következik be. Ennek következtében léphetnek fel olyan folyamatok, amelyek a leletek mennyisége és minősége szempontjából meghatározóak lehetnek. A beágyazódás folyamata a legtöbb esetben allochton. ${ }^{60}$ A leletek szempontjából a szállítódás ténye alapvető veszteségnövelő tényező, különösen, ha ún. akadályozott szállítódásról van szó, amely a mozgó és a mozdulatlan szállítóközeg határfelületén történik. ${ }^{61}$ A tafonómiai veszteség kétféle módon nyilvánulhat meg: ${ }^{62}$

- Analóg: amikor a hasonló leletveszteséget eltérő hatások eredményezik.

- Homológ: amikor a leletveszteséget azonos hatások idézik elő, de azok eltérően nyilvánulnak meg.

A tafonómiai folyamatokat kiváltó közvetlen hatásokat, tafonómiai tényezőknek (taphonomic agent) nevezzük. A tafonómiai tényzők tehát azok a közvetlen erők vagy hatások, amelyek változásokat idéznek elő az állatmaradványban, illetve közvetlenül a csontszövetben. ${ }^{63}$ Ilyen lehet maga a gravitáció, illetve különböző emberi vagy állati ráhatások. Ezeknek a tényezőknek a dinamikus munkájaként értelmezhetjük magukat a tafonómiai folyamatokat (taphonomic processes). ${ }^{64}$

55 Bartosiewicz 2006, 60; Jefremov 1940, 93. Mindezek mellett a szerző fontosnak tartja megjegyezni azt is, hogy nem önálló tudományról van szó!

56 GÉCZY 1984, 90-97.

57 GÉCZY 1984, 90.

58 GÉCZY 1984, 90.

59 GÉCZY 1984, 92.

60 GÉCZY 1984, 92.

61 GÉCZy 1984, 92.

62 BARTosiewicz 2006, 62.

63 LyMAN 1994, 3.

64 Lyman 1994, 3. 
Az állat elhullása után, a bomló test tafonómiai története (taphonomic history) voltaképpen egyből a második lépcsőfokkal, a tafonómiai folyamatok megindulásával veszi kezdetét. A tafonómiai folyamatok tulajdonképp három dimenzión keresztül hathatnak az állatmaradványokra: ${ }^{65}$

Az OBJEKTUM dimenzióján keresztül:

- hozzáadódás

- kivonódás

- fennmaradás

Az ELOSZLÁS dimenzióján keresztül:

- mozgatott

- nem mozgatott

A VÁLTOZÁS dimenzióján keresztül:

- változtatott (természeti, vagy antropogén hatás)

- nem változtatott

Ezt követi a szétesés (dissarticulation) folyamata, mely a csontok anatómiai rendjének megbomlását eredményezi. A tafonómiai történet következő lépéseként a szétszóródással (dispersal) kell számolnunk, melyet jelentősen befolyásolnak a különböző áthalmozódási folyamatok. ${ }^{66}$ A csontok áthalmozódási folyamatának törvényszerüségeit Shotwell írta le 1955-ben megjelent cikkében. ${ }^{67}$ Mindezek után a fosszilizáció (fossilization) folyamata jön sorra, mellyel egy időben, vagy azt követően mechanikus változások (mechanical alteration) is történhetnek. Ezek lehetnek strukturális és/vagy morfológiai átalakulások.

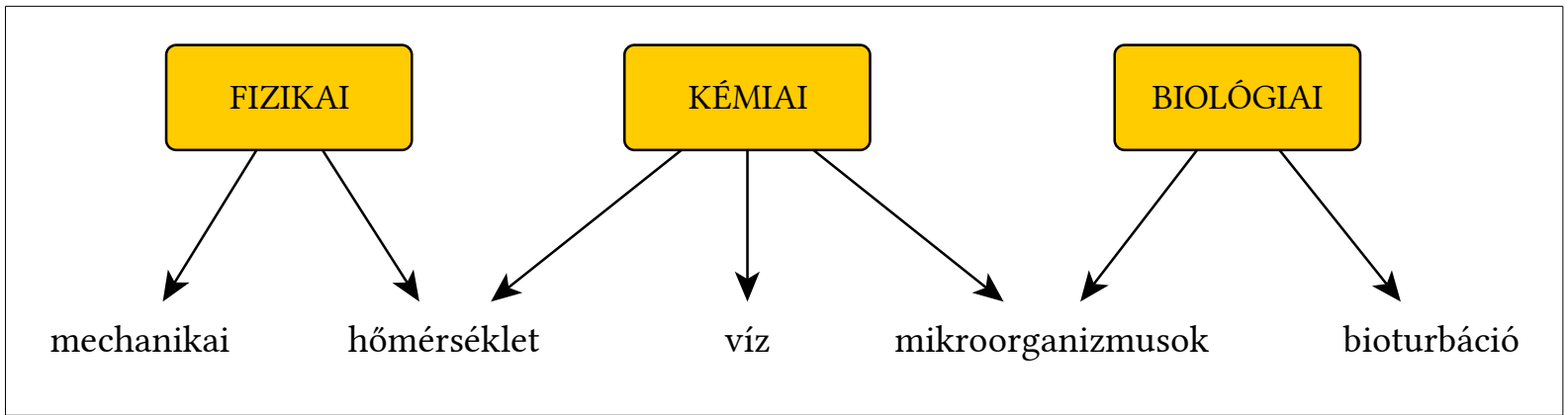

Fig. 5. A fosszilis diagenezis folyamatát befolyásoló hatások. Influence factors of the fosiliss diagenesis (after BARTOsIEwICZ 2006).

Ez utóbbiak együttesen alkotják a tafonómiai folyamatok második nagy szakaszát a fosszilis diagenézist (Fig. 5). Ezen az átalakuláson azokat a történéseket értjük, melyek a beágyazódástól a jelenleg észlelt állapot eléréséig tartanak. ${ }^{68} \mathrm{~A}$ kövesedés folyamata, a diagenezis, ugyancsak három dimenzión keresztül zajlik : ${ }^{69}$ 
- a csont üregeiben

- magában a csontszövetben

- a csontot befogadó üledékben, vagy kőzetben

Ezt a három dimenziót pedig az alábbi hatások érhetik $:^{70}$

- Mechanikai hatások:

- tiprás

- talajnyomás

- dörzshatás

- deformáció

- Hőhatások:

- égés

- fagyás

- fagyás-felengedés váltakozása (krioturbáció)

- Víz okozta hatások:

- tömörülés, cementálódás (kompakció)

- kimosódás (szolúció)

- A talaj pH hatásai:

- savas

- lúgos

- Enzimek-mikroorganizmusok hatásai

- Bioturbáció

A tafonómiai folyamat e két fő szakasza során az élő közösség (biocönózis) így alakul át halotti közösséggé (tanatocönózis), majd a tafonómiai folyamatok által „szelektált” tafonómiai közösséggé. Ez utóbbi a tafocönózis. A képet némiképp árnyalhatják olyan folyamatok, melyek összemoshatnak több tafonómiai társulást, létrehozva ezzel egy kevert társulási formát az oriktocönózist. ${ }^{11}$ Végezetül pedig mindezek együttesen hozzák létre azokat a tafonómiai eredményeket, vagy nyomokat (effects or traces), amelyekkel aztán a tafonómiai vizsgálatok során szembesülünk. ${ }^{72}$

Régészeti szempontból a tafonómia tudományágként a leírtaktól kissé eltérő színezetet kap. Esetünkben egy igen jelentős és intenzív módosító hatással kell számolnunk. Ez pedig nem más, mint az emberi tényező. A kulturális szűrők (cultural filter) alapvetően befolyásolják a potenciális állat- és az abból származó csontpopulációt. ${ }^{73}$ A tafonómiai elemzés szempontjából megkülönböztethetünk: ${ }^{74}$

- elsőrendü folyamatokat

- másodrendủ folyamatokat 
Míg az előbbi a kutató(k)tól független, hiszen a korabeli biotikus és abiotikus folyamatokat összesíti, addig az utóbbi a felfedezés, a feltárás kezdetétől a végleges raktári elhelyezésig érvényesülő emberi hatásokat foglalja magába (Fig. 6).

\section{NEM BEFOLYÁSOLHATÓ TÉNYEZŐK}

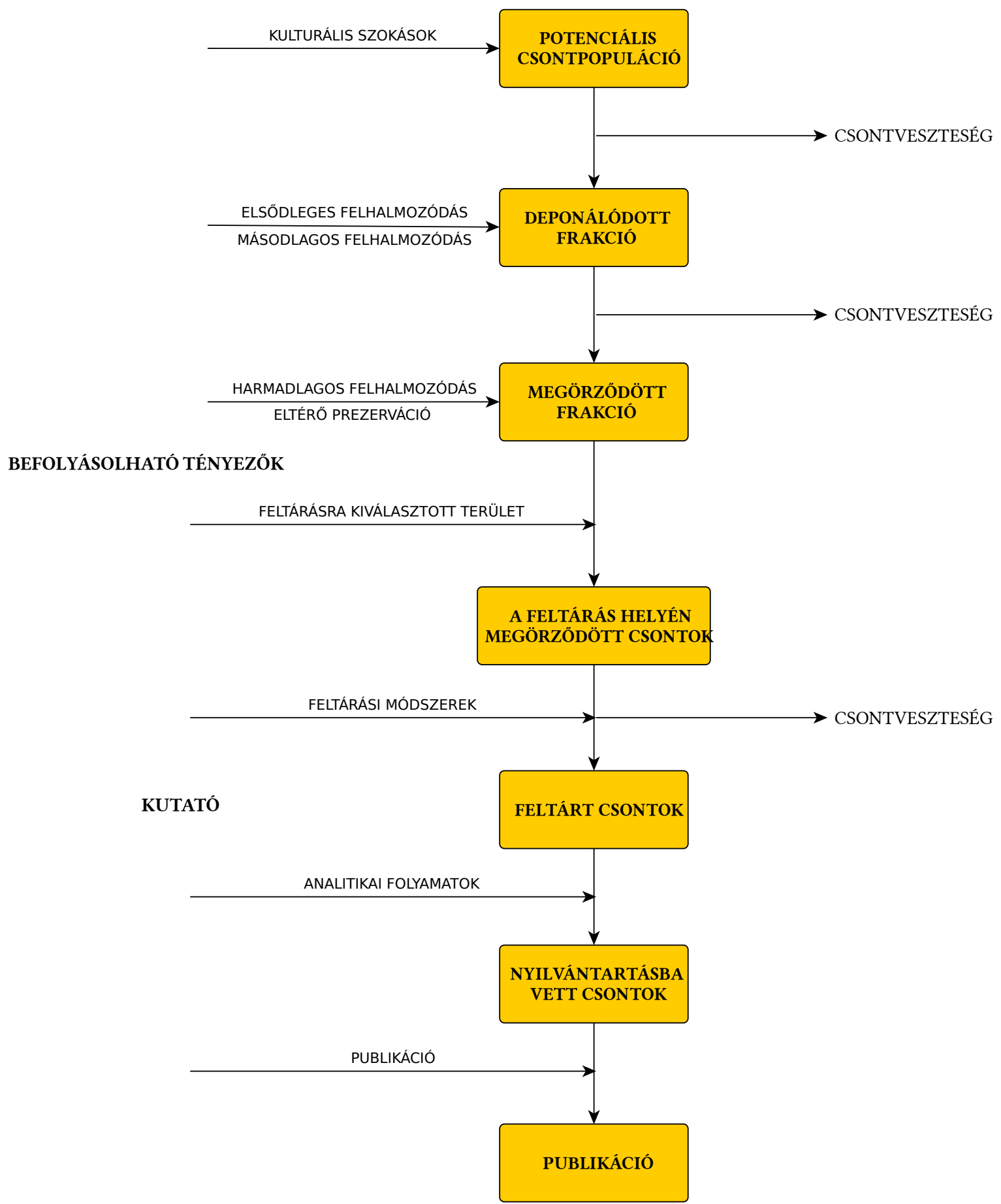

Fig. 6. Az első- és másodrendű tafonómiai folyamatok ábrája. First- and second class taphonomical processes (after MEADOw 1981). 
Az elsőrendű kulturális szempontú biosztratinómiai folyamatok értelmezésének első lépése - kizárólag régészeti, illetve archaeozoológiai szempontok alapján - az állattani anyag eredetének vizsgálata. Ezt a rendelkezésre álló vad-, illetve háziállatok felhasználásának aránya fejezi ki. ${ }^{75}$ Ez már alapvetően, a kultúra társadalmi normái, valamint technológiai háttere által jelentősen befolyásolt szelektív folyamat (resource management) eredménye, melyet kiegészítenek és/vagy leszűkítenek a lakott terület közvetlen környezete által kínált természeti források (catchment area).

Ezt követi annak megállapítása, hogy az elfogyasztott, vagy másképpen hasznosított állatok milyen korú és nemű egyedeit használták fel. Ez a szelekció második lépcsőfoka. ${ }^{76}$ Bizonyos nemű, vagy korú egyedek hiánya vagy többlete az adott faj hasznosítási módozataira is utalhat. ${ }^{77}$ Sok esetben - talán kimondhatjuk, hogy általánosan - az elsődleges darabolásoknak köszönhetően a teljes állati vázak nem kerülnek bele a hagyományos értelemben vett konyhai hulladékba. Az elejtés, vagy vágás helyén történő elsődleges feldolgozási folyamatok után már csak további feldolgozásra szánt testrészeket szállítják tovább a feldolgozás következő állomására, amely történeti kortól függően lehet hússzék, vagy akár egyszerủ háztartás is. Itt következhetnek be az ún. másodlagos aprítási folyamatok, melyek további komoly tafonómiai veszteséget okozhatnak. ${ }^{78}$

A legutolsó veszteségokozó tényezők maguk az eltemetődési, vagy deponálódási folyamatok. ${ }^{79}$ A tulajdonképpeni felhalmozódási típusok meghatározása nem csupán a tafonómiai folyamatok megismerése szempontjából, hanem a későbbi interpretáció szempontjából is nagyon fontos. ${ }^{80}$ Egy nyitott, kevéssé védett hulladék jobban kitett olyan folyamatoknak, amelyek fokozzák a tafonómiai veszteséget (pl.: a kutyák csontpusztító tevékenysége, taposás stb.). A felhalmozódás típusa lehet:

- tényleges háztartási hulladék

- vágó-, vagy feldolgozóhely hulladéka

- tényleges eltemetés

Nyilvánvaló, hogy a fent felsorolt deponálódási formák más-más jellegű fennmaradást eredményeznek, ezért szem előtt tartásuk kiemelten fontos a tafonómiai analízis szempontjából. Maga a tafonómiai elemzés mindezek alapján az alábbi analitikai kategóriák értelmezésén alapul. Ezek hierarchikus rendszere, mintegy egymásba fészkelt (azaz egymásból következő, ám önálló) rendszerként értelmezhető (Fig. 7).

A tafonómiai folyamatok, illetve azok tudatos értékelése tehát alapvetően befolyásolja mintegy kalibrálja - a leletek képződéséről alkotott képünket. A tafonómiai rendszerek és szemlélet felhasználásával a hiány arányának becslése és értelmezése is lehetővé válik. 


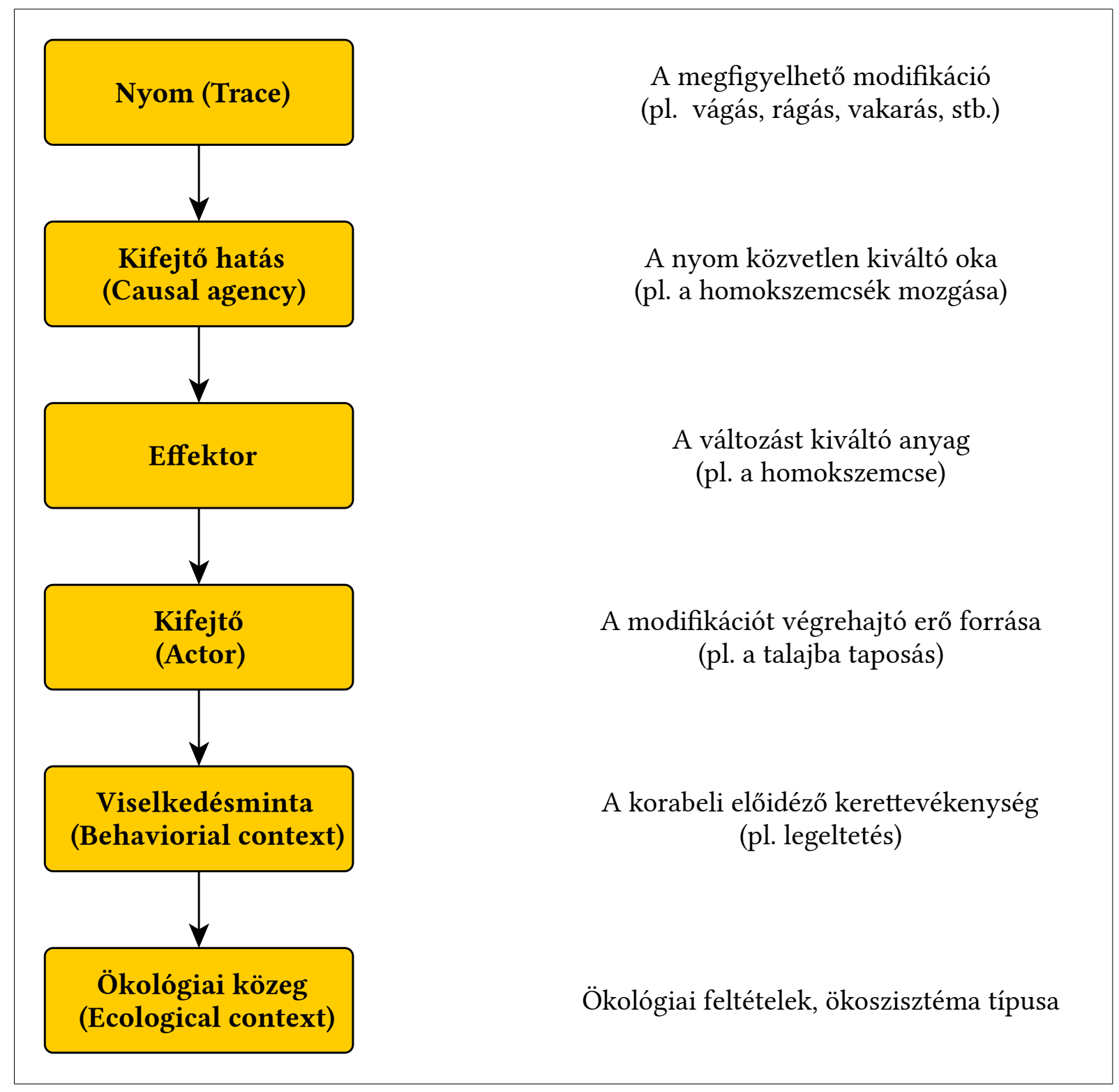

Fig. 7. A tafonómia analitikai kategóriáinak egymásba fészkelt rendszere. Nested system of the analitical categories of the taphonomic processes (after LymAN 1994).

\section{Az állatcsontok értelmezésének alapfeltevései}

Amennyiben elfogadjuk a fentiekben felállított axiómát; miszerint az állatcsontok nem csupán szerves környezeti maradványként értelmezhetőek, hanem mint a korabeli emberi tevékenység manifesztumai, olyan kérdések merülnek fel, minthogy lehetséges-e a tárgyleletekhez hasonlóan osztályozási, vagy egyéb megfigyelhető kategóriákat felállítani az állatcsont leletek kapcsán? Léteznek-e a fentihez hasonló értelmezési szintek az állatcsontok esetében?

$\mathrm{Az}$ ásatásokon előkerült állatmaradványok legnagyobb része az egykori a településeken élt emberek étkezési szokásainak közvetett bizonyítéka. Bizonyítéka annak, hogy a hús minden régészeti korszakban a meghatározó táplálék volt, így a településen, vagy annak közelében élő állatok jelentős táplálékforrást jelentettek. Az állatcsontok tehát elsősorban a mindenkori 
húsfogyasztásra mutatnak rá. ${ }^{81}$ Hogy megválaszolhassuk mit is ettek az egykori települések emberei, tehát szükséges az állatcsontok feldolgozása és értékelése. A pusztán vadászatra szakosodott vadászó-gyủjtögető csoportoktól eltekintve, az ember a körülötte élő háziállatokból fedezte hússzükségletének legnagyobb részét, amely kevesebb utánajárást, ám komolyabb és szervezettebb állattartási ismereteket követelt. ${ }^{82}$

A fejlettebb állattartási ismeretek az állatok tenyésztését feltételezik. Mindebből az következik, hogy az állatmaradványok alapján az állattartási szokásokra is következtethetünk. ${ }^{83}$ Ezt azonban csak igen hiányosan tehetjük, hiszen a mindenkori köz- és/vagy egyéni ízlésnek, a technológiai tudásnak és praktikumnak megfelelően vágták le az állatokat. A feltárt csontmaradványok tehát egy kulturális és technológiai szűrőn estek keresztül. Ezeket a kulturális szűrőket egészítik ki, vagy még inkább ezek szelekciós hatását erősítik az előző alfejezetben részletesen tárgyalt tafonómiai folyamatok.

A háziállatok mellett ugyanakkor vadállatok csontjai is feltűnnek a leletanyagban. Ezek alapvetően négyféleképpen kerülhetnek bele a csontanyagba:

- tudatos vadászat

- nyersanyaggyüjtés (pl. agancs)

- táplálékgyűjtés (pl. kagyló, csiga)

- tafonómiai nyereség (talajlakó állatok)

Az első kategória nem igényel különösebb magyarázatot. A vadászat a korai időkben, illetve a vadászó-gyűjtögető csoportoknál az állati fehérje megszerzésének alapvető eszköze volt. ${ }^{84}$ A vadászat jelensége a történeti koroktól napjainkig folyamatos, jóllehet funkciója egyre inkább a szórakozás, illetve a vadállomány szabályozása, mintsem az alapvető fehérjeszükséglet biztosítása. A vadászat tehát a könnyebben hozzáférhető háziállatok tartásával is tovább él, ámbár jelentősége számottevően csökken. ${ }^{85} \mathrm{~A}$ vadászat mögött sokkal inkább láthatunk tehát kulturális jelenséget, mint létfenntartó stratégiát. A vadak jelenléte bizonyos keretek között fontos környezet-rekonstrukciós forrásként is használható.

Az állati maradványok, mint a nyersanyaggyüjtő tevékenység következményeként a településekre került anyagok magyarázata a csont- és agancsmegmunkálásban rejlik. A gímszarvas (Cervus elaphus L.), valamint az európai őz (Capreolus capreolus L.) agancsa kiváló alapanyag, a különböző nagy rugalmasságot és szilárdságot kívánó eszközök számára. ${ }^{86}$ Mivel ezek az állatok ciklikusan, évente hullajtják agancsukat, nem szükséges okvetlenül az állat leölése a nyersanyag megszerzéséhez. Emiatt a telepeken talált agancsmaradványok nem bizonyítják egyértelműen az állatok vadászatát. ${ }^{87} \mathrm{Az}$ állat vadászata mellett szól azonban, amennyiben a koponyára még ránőtt, nem hullajtott aganccsal találkozunk.

81 Bartosiewicz 2006, 38. Ez természetesen a hagyományos értelemben vett konyhahulladékra igaz, hiszen az egészben elföldelt, esetleg áldozatként bemutatott, vagy más természetes úton elhullott állatok tetemei nem értelmezhetőek elfogyasztott egyedekként.

82 BARTOSIEWICZ 2006, 89; MATOLCSI 1975, 8

83 Bartosiewicz 2006, 148; CSIPpÁn 2008.

84 VÖRÖs 2003.

85 BARTOSIEWICZ 2006, 85.

86 Bartosiewicz 2006, 175; Choyke 1987.

87 Bartosiewicz 2006, 165. 
A táplálékgyűjtés valódi bizonyítékai a nagy csoportban, egyszerre feltűnő, sokszor a sütés, vagy főzés nyomait magukon viselő puhatestű házak. Ezek fogyasztása minden bizonnyal szezonális jellegű lehetett és csak, mint kiegészítő táplálék lehetett szerepük az étkezésben. Gyüjtésükre természetesen csak a megfelelő környezeti feltételek mellett kerülhetett sor ezért ezek jelenléte is fontos környezetrekonstrukciós forrás. Az esetlegesen kereskedelmi kapcsolatok révén bekerült puhatestű maradványok nyilvánvalóan a társadalmi kapcsolatokban játszhattak szerepet, étkezési szokásokkal egészen a római provinciális korig nem hozhatóak összefüggésbe.

Hasonló értelmezési lehetőség vonatkozik a halakra és a hozzájuk kötődő halászati tevékenységre is. A rendelkezésre álló halállományt szinte bizonyosan kiaknázták valamilyen módon, ám mindennek csupán táplálék kiegészítő jellege lehetett. Pusztán halak fogyasztására specializálódott kultúráról nincs tudomásunk, ám az elfogyasztott halak típusa népcsoportra jellemző, kulturálisan szabályozott lehet. ${ }^{88}$

Végül a vadcsontok bekerülésének egy természetes útjáról is meg kell emlékeznünk. Ez az úgynevezett tafonómiai nyereség fogalma. A lelőhelyek objektumai, gödrei puha betöltésük révén eszményi járatkialakítási lehetőséget kínálnak a különböző kotoréklakó állatfajok (Crotovina) számára. Az egyes rágcsáló és más kisemlős fajok előszeretettel ássák be magukat régészeti objektumokba, így előkerülésük sok esetben nincs semmilyen viszonyban az egykoron ott élt emberek táplálkozási szokásaival. Ugyanez vonatkozhat mocsaras lelőhelyek esetében a puhatestű-, kétéltü- vagy hüllőfajokra is. Ezért ezen leletek értékelésénél igen körültekintően kell eljárni. A fenti kijelentésekhez kétféle következtetés csoport kapcsolható: zoológiai és kulturális következtetések.

\section{Zoológiai következtetések}

Az állatcsont, mint leletanyag, amennyiben követjük a Renfrew - Bahn kézikönyv besorolását, a szerves környezeti maradványok közé tartozik. Itt most eltekintünk a fenti alfejezetekben leírtaktól és elfogadva, hogy ezen leletanyagtípus elsősorban a „természeti” környezetre utal, kísérletet tehetünk arra, hogy összefoglaljuk, hogy milyen biológiai, vagy biológiai jellegű információkat hordoz magában. A feldolgozás során természetesen a biológiai információk is több szinten mutatkozhatnak meg az adott leletanyagban. ${ }^{89}$

Az archaeozoológiai szakirodalomban általában elkülönítenek elsődleges és másodlagos adatokat, illetve ezen adatok nyújtotta információkat. ${ }^{90}$ Ezek elkülönítése tulajdonképpen a zoológiai analízis mélységét, illetve szintjeit is jól érzékeltetik. E két kategória azonban bővítésre szorul, hiszen az első és másodlagos információkat együttesen felhasználó elemzés mindenképp magasabb analitikai szintet képvisel.

Az elsődleges adatok olyan alapvető zoológiai információkkal szolgálnak, melyek megállapítása egyfelől minden további elemzés alapja, másrészt - mivel az adatgyüjtés módszere a hagyományos paleontológiai analízis adatgyüjtési módszereinek mintájára épül - elsősorban paleozoológiai jellegűek. ${ }^{91}$

88 DARÓCZI-SZABó 2002

89 ReITZ - WING 1999, 149.

90 ReITZ - Wing 1999, 143.

91 Reitz - Wing 1999, 321. Jóllehet az elsődleges szemrevételezések során egyértelművé váló jelenség, így elsődleges információnak tekinthető az adott csont esetleges megmunkáltsága, azonban jelen felosztás alapján ennek részletes tárgyalására a későbbiekben kerül sor. 
- A feldolgozott állati maradványok száma.

- A fajpontosan meghatározott (NISP) és a meghatározhatatlan maradványok száma.

- A meghatározott fajok megoszlása.

- A csont irányultsága.

- A töredék jellege.

- A töredék testtájék szerinti orientációja.

- A leletanyag megtartása.

- Az állatok életkora.

- Az állatok neme. ${ }^{92}$

- A leletanyag súlya.

- A csontokon megjelenő patológiás elváltozások.

- Méretek.

- Töredezettség.

- Tafonómiai folyamatok hatása.

- Paleokörnyezeti rekonstrukció

- a település háziállatai (a biológiai populáció karakterisztikája)

- a település környezetének jellege

- az állatok élőhelye

- $\operatorname{vad}$

- házi

- környezetátalakítási folyamatok

- klimatikus viszonyok

- a terület eltartóképessége

- forrásterület

- niche szélesség

A fenti információk természetesen erősen szelektáltak mind a tafonómiai és a kulturális folyamatok, mind pedig az ásatási technológia és a feltárási lehetőségek által.

Az olyan alapvető információkon túl, minthogy mennyi a pontosan (faj szerint) meghatározott töredékek száma (Number of Identifiable SPecimens), a leletanyagban megfigyelhető állatfajok aránya, milyen csontok fordulnak elő elsősorban; metrikus és ezáltal összehasonlítható adatokhoz is jutunk az analízis első lépései során. A pontos méretek levételét az adott töredékekről vagy ép csontokról nemzetközi, a szakma által elfogadott szabványok írják elö. ${ }^{93}$ Fontos metrikus adat még a csonttöredékek tömege is. ${ }^{94}$ A pontos tömegadatok alapján

92 Ebben esetben a pusztán szemrevételezéssel megállapítható nemi jellegekről van szó.

93 VON DEN DRIESCH 1976.

94 Fontos azonban megjegyeznünk, hogy a prezerváció mértéke, a cementálódás, illetve a fosszilis diagenezis előrehaladottsága jelentősen befolyásolja a csonttöredékek tömegét. 
pedig megkísérelhető az elfogyasztott húsmennyiség hozzávetőleges kiszámítása is, illetve a biomassza tömegének becslése. ${ }^{95}$ Jóllehet ezek az adatok már sokkal inkább a másodlagos kategóriába tartoznak.

Mindezeken túl elsődleges adatnak számítanak olyan - szintén szemrevételezéssel megállapítható - adatok, mint az epifízisek elcsontosodása, vagy a fogak kihasadása, illetve kopása alapján megállapítható relatív kor, valamint néhány egyértelmű esetben az állat neme, továbbá a csontokon megfigyelhető kóros elváltozások.

A csonttöredékek részletes szemrevételezése után az elsődlegesen megállapított biológiai adatok alapján nyílik lehetőség az analízis következő lépésének megtételére, az ún. másodlagos információk összegyüjtésére. ${ }^{96} \mathrm{~A}$ másodlagos adatok olyan, többnyire szemrevételezéssel meg nem állapítható információkat tartalmaznak, melyekhez az elsődleges adatokkal végzett összesítések, számítások, vagy egyéb statisztikai eljárások segítségével juthatunk hozzá. ${ }^{97}$

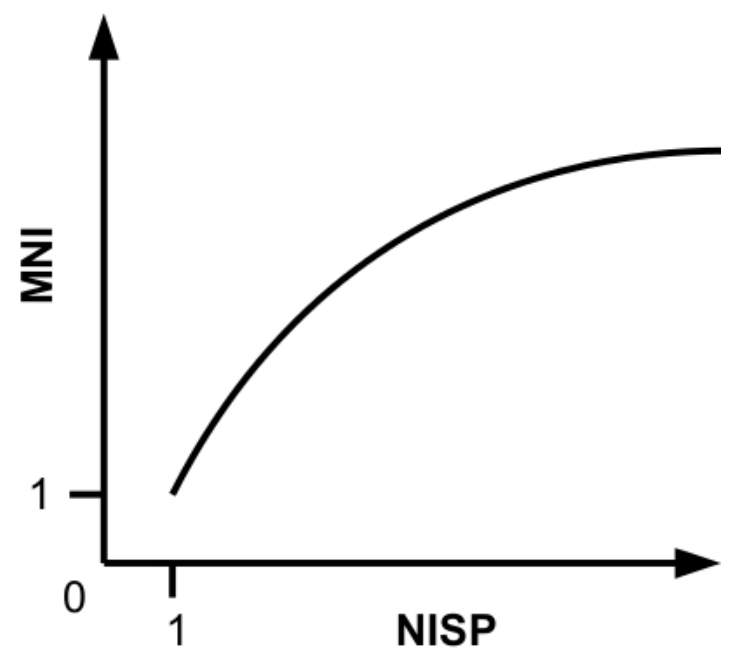

Fig. 8. Az egyedszám és a töredékszám elméleti összefüggése. Dependencies between NISP and MNI (after LyMAN 2008).

A meghatározott csontok száma (NISP) alapján legkézenfekvőbben megállapítható jelenség az egyes fajok gyakorisága, illetve ezen gyakoriságok fajonkénti sorrendje. A mennyiségeken túl a csontok vagy csonttöredékek orientációja, illetve vázon belüli elhelyezkedése alapján olyan nagyobb egységek figyelhetők meg, mint a különböző testrégiók alul-, vagy felülreprezentáltsága, ${ }^{98}$ vagy a minimális egyedszám (Minumum Number of Individuals) és ezen keresztül a faji diverzitás (Fig. 8). ${ }^{99}$

A minimális egyedszám számítása, illetve ennek megítélése meglehetősen vegyes az archaeozoológiai szakirodalomban. Alapvetően problematikus már maga a számítás helyes módjának megállapítása is. A nemzetközi szakirodalom alapján hozzávetőlegesen is több mint egy tucatnyi definíció és módszer létezik a minimális egyedszám pontos megállapítására. ${ }^{100} \mathrm{~A}$ minimális egyedszám használata mellett és ellen számos érv sorakozik fel. Előnyei, hogy kézzelfoghatóbb képet fest az állatok számáról, közvetlenebb információkkal szolgál a fajgyakorisággal kapcsolatban, valamint kiküszöböli a meghatározott darabszám (NISP) azon hátrányát, hogy az összesítések során ugyanannak a csontnak, vagy akár ugyanannak az állatváznak több töredéke is megjelenhet külön-külön értéket képviselve. Ez nyilván valamilyen szinten torz képet adhat, hiszen korántsem mindegy, hogy egyetlen állatfaj 100 db csontjával, vagy csupán egyetlen állat $100 \mathrm{db}$ csontjával állunk szemben. ${ }^{101}$

95 BARTosiewicz 1988.

96 ReItz - Wing 1999, 171.

97 Reitz - Wing 1999, 171.

98 CSIPPÁN 2007, 93

99 LyMAN 2008, 192.

100 LyMAN 2008, 40.

101 LyMAN 2008, 43. 
A fenti előnyökkel szemben azonban lényegesebbek és számosabbak a módszer hiányosságai. A minimális egyedszám elsősorban olyan leletek vizsgálatánál lehet hasznos, melyek deponálódása feltehetően egyszerre, vagy legalábbis jól behatárolható időintervallumon belül ment végbe. A régészeti leletanyag esetében az adott deponálódási folyamatok sokszor évtizedeket, vagy akár évszázadokat is igénybe vehetnek. Ugyanakkor egy-egy hulladékgödör betemetődése akár pár nap alatt is végbemehetett. A régészet esetében a konkrét időintervallum tehát nem mindig határozható meg egyértelműen. Az így kapott egyedszám pedig pontos időkorlátok nélkül irreleváns információ. A minimális egyedszám használata csakis az olyan kompakt, konyhahulladékként nem értelmezhető jelenségeknél lehet célravezető, amelyeknél a deponáció egyetlen lépésben zajlott le és a takaró réteg azonnal el is fedte a deponált váza(ka)t. Ilyen jelenségek a sírok, az áldozatok, a sírmellékletek, valamint természeti katasztrófák következményei.

A számítás további hátrányai, hogy:102

- Nehézkes és hosszadalmas számítás.

- A sokféle számítási módszer gátolja a lelőhelyek közötti összehasonlítást.

- A számított egyedszámok nem okvetlenül tükrözik a tényleges tanato-, vagy biocönózisra.

- Az egyedszámok eltúlozhatják egy-egy állatfaj jelentőségét, ritka fajok, vagy alacsony csontszám (NISP) esetében.

- A megállapított egyedszámok csak a minimumot mutatják, így tényleges fajgyakoriság nem állapítható meg belőlük.

- Az aggregációs hatás, azaz egyazon egyed több objektumból előkerülő csontjainak félrevezető összeadódása. ${ }^{103}$

A minimális egyedszám minden esetben elvégzett számításának fontossága azért is megkérdőjelezhető, mert értéke szorosan összefügg a meghatározott darabszámtól. Olyannyira, hogy tulajdonképp arányait tekintve azzal majdhogynem megegyezik. ${ }^{104}$

Másodlagos információnak számítanak továbbá a csontok méretei alapján számított morfometriai dimenziók (marmagasság, méretbeli gyakoriságok, eloszlások stb.). A marmagasságok számítása fajonként eltérő, ezek mindegyikéhez külön szerző társul, így idézésüktől itt eltekintek (minden felhasznált szerző munkája szerepel az irodalomjegyzékben), vagy az ivariság ugyancsak a méretek alapján végzett megállapítása is. ${ }^{105}$

Harmadlagos információként értelmezhetőek azok az adatok, melyek nem konkrétan az állatok morfológiájára, vagy az egyed szintjén megfigyelhető jelenségekre vonatkoznak, hanem magasabb szinteket, az adott fajpopulációkat képviselik. Ilyen jellegü információk lehetnek

102 Lyman 2008, 46.

103 Bartosiewicz 2006, 159.

104 A minimális egyedszám használatának kiküszöbölését szolgáló módszer lehet, amennyiben az összetartozó vázak és vázrészek - az egyes csonttöredékekhez hasonlóan - egy esetként kerülnek rögzítésre az adatbázisokban. A tényleges csonttöredékek száma így is könnyedén nyilvántartható, ám az összesítés során nem működik torzító tényezőként. Ez a módszer valamelyest közelíti az NISP és az MNI értékeit, mégsem kell bonyolultabb és nem feltétlenül célravezető számításokba bocsátkozni.

105 Noвis 1954; MAтоLCSI 1970; Цалкин 1960. A marmagasságok számítása fajonként eltérő, ezek mindegyikéhez külön szerző társul, így idézésüktől itt eltekintek. 
egyrészt az elfogyasztott állatok közösségének jellemzői - például a már említett fajgyakoriságok, állomány összetétel -, másrészt az állatfajok környezetjelző szerepén keresztül a paleokörnyezet rekonstruálásának lehetősége. ${ }^{106}$

A környezeti rekonstrukció, az emberi és állati társadalmak sajátos ökológiája olyan jelenségekre hívhatja fel a figyelmet, melyek megállapítása alapvetően meghatározhatja az adott közösség életéről alkotott képünket. A rendelkezésre álló és a ténylegesen kihasznált forráslehetőségek vizsgálata, valamint összefüggéseik magyarázata azonban már sokkal inkább a kulturális következtetések sorába tartozik.

Napjainkban a fenti információk olyan talán negyedlegesnek nevezhető adatokkal egészülhetnek ki, mint a különböző kémiai és/vagy mikrobiológiai analízisek (izotópvizsgálatok, DNS-elemzés stb.) eredményei. Az egyes fajok eredetének és elterjedésének biokémiai kutatása meghatározó új irányzattá vált az elmúlt években az archaeozoológiában.

Ezen biológiai adatok és információk összességében számos összehasonlításra, statisztikai számítások bevonására adnak lehetőséget. Mindezeken túl azonban továbbra is közelebb állnak a hagyományos értelemben vett paleontológiai vizsgálatokhoz, hiszen esetükben az emberi hatás, a kulturális szűrő viszonylag kevés hangsúlyt kap.

\section{Kulturális következtetések}

Az állatcsontleletek, mint a korabeli emberi tevékenység tárgyi emlékei, elsődlegesen a húsfogyasztásra reflektálnak. ${ }^{107}$ Nyilvánvalóan e tekintetben remélhetjük a régészeti szempontból legrelevánsabbnak mondható információkat ettől a leletanyag típustól. A fellelt állati maradványokból levont mindennemü következtetések tehát csakis ennek figyelembevételével, illetve ezen megállapításon keresztül valósíthatóak meg. Az archaeozoológiai értékelés tehát minden esetben nem csupán az adott népesség kulturális szűrőjén, hanem annak egy sokkal finomabb részén, a húsfogyasztás szürőjén keresztül zajlik. Mindez azt jelenti, hogy elemzéseink sohasem lehetnek teljesek és véglegesek, mivel azonban ezen megállapítás a régészettudományra is érvényes, a archaeozoológiai vizsgálatok szervesen illeszkedhetnek a régészeti kutatás egészébe.

A csonttöredékek részletes szemrevételezése során nem csupán biológiai jellegű adatok kerülnek az elemzést végző archaeozoológus birtokába. A biológiai adatokhoz hasonlóan ebben az esetben is elkülöníthetünk elsődleges és másodlagos információkat. Az értelmezés szintje ugyan itt is egymásra épül mégis a már eleve magasabb analitikai kategóriákat érintő elemzést nem biztos, hogy szerencsés további szintekre emelni, hiszen az könnyen az érthetőség és átláthatóság rovására mehet. Reitz és Wing alapján a kulturális következtetések a következő területeket fedik le: ${ }^{108}$

106 A paleokörnyezeti rekonstrukció természetesen pusztán a gerinces nagyemlősök elemzése alapján nem lehetséges. Az archaeobotanikai, malakológiai, pollen-, fitolit- és kisemlősvizsgálatok nélkül a természeti környezet rekonstrukciója pusztán vázlatszerủ lehet. Ezen vázlat azonban további vizsgálatok alapjául szolgálhat.

$107 \mathrm{Ez}$ a megállapítás természetesen nem vonatkozik a szakrális, vagy egyéb, az étkezéssel összefüggésbe nem hozható csontleletekre.

108 REITZ - WING 1999, 321-326. 
- Létfenntartási stratégia.

- Húsfogyasztási szokások.

- Állattartási szokások, ismeretek.

- Állattartási és állat hasznosítási technológia.

- Gazdasági berendezkedés. ${ }^{109}$

- Állati termékek előállítása:

- húsfeldolgozás

- bőrmegmunkálás

- csontmüvesség

- gyapjúfelhasználás

- tejtermékek előállítása

- Kereskedelmi és elosztási rendszerek (mikro- és makrogazdaság)

- Ideológiai képzettársítások, asszociációk

- étkezési tilalmak és tabuk

- szociális státusz és presztízs

- vallási hiedelmek

Bizonyos tekintetben elsődleges információként kezelhetünk olyan, már a szemrevételezés során megfigyelhető jelenségeket, mint a csonttöredék égettsége, a rajtuk lévő darabolás, vagy megmunkálásnyomok, esetleg kóros elváltozások. Ezek az adatok jelentős információkat szolgáltathatnak úgy az állatok tartása, felhasználása, mint a feldolgozás technológiája tekintetében. Míg bizonyos típusú vágásnyomok az adott állat nyúzását bizonyítják, addig más vágás- és hasításnyomok egyértelműen az állat darabolására utalhatnak. Az égésnyomok a sütés-fózés közvetett bizonyítékaként értelmezhetőek, sok esetben azonban a hulladék felgyújtására, így célzott hulladékgazdálkodásra is utalhatnak. A csontokon megfigyelhető kórós elváltozások, illetve azok gyógyultsága is információval szolgálhat az állatok tartásával, ellátásával és gyógyításával kapcsolatban, hiszen a beteg állat túlélése mindenképp valamilyen gondoskodás, de legalábbis az állat kímélésének bizonyítéka.

További gazdasági következtetésekhez vezet a mortalitás vizsgálata. A haszon-állatok feltételezett szaporulatának függvényében, a felhasználásban szezonalitás is nyomon követhető. A levágott egyedek relatív korának megállapítása információkkal szolgálhat az állatok további úgynevezett másodlagos hasznosításával kapcsolatban. ${ }^{110}$ Ezek a felhasználás típusok nem igénylik az állat leölését csupán az ún. élőhasznát aknázzák ki. Ilyen élőhaszon az állatok gyapja és teje, ide tartozik egyes állatfajok igaereje, mobilitási szerepe (lovagolhatóság, fogatolhatóság), vagy őrző-védő használata, esetleg társ funkciója. Jóllehet ez utóbbi kategóriák már a magasabb szintű értelmezési szintekhez tartoznak, a határok azonban itt nem olyan egyértelműen meghúzhatóak, mint a biológiai információk esetében.

109 Ebben a tekintetben természetesen csupán az állattartással, illetve az állatok felhasználásával összefüggésbe hozható gazdasági tevékenységekről lehet szó.

110 BARTOSIEWICZ 2006, 89. 
A kulturális következtetések szempontjából egyértelműen másodlagos információnak tekinthetjük azokat a jelenségeket, melyek összefüggésben állnak a csontok kontextusával, így az állat elfogyasztásával (preferált fajok, preferált testrégiók stb.), valamint azokkal a jelenségekkel, melyek túlmutatnak a húsfogyasztáson. (pl. sírok, sírmellékletek, áldozatok). Ezek az adatok szinte minden esetben olyan közvetett információk, melyek több alapinformáció összevonásával, illetve azok komplexebb elemzésével tárhatóak fel (Fig. 9).

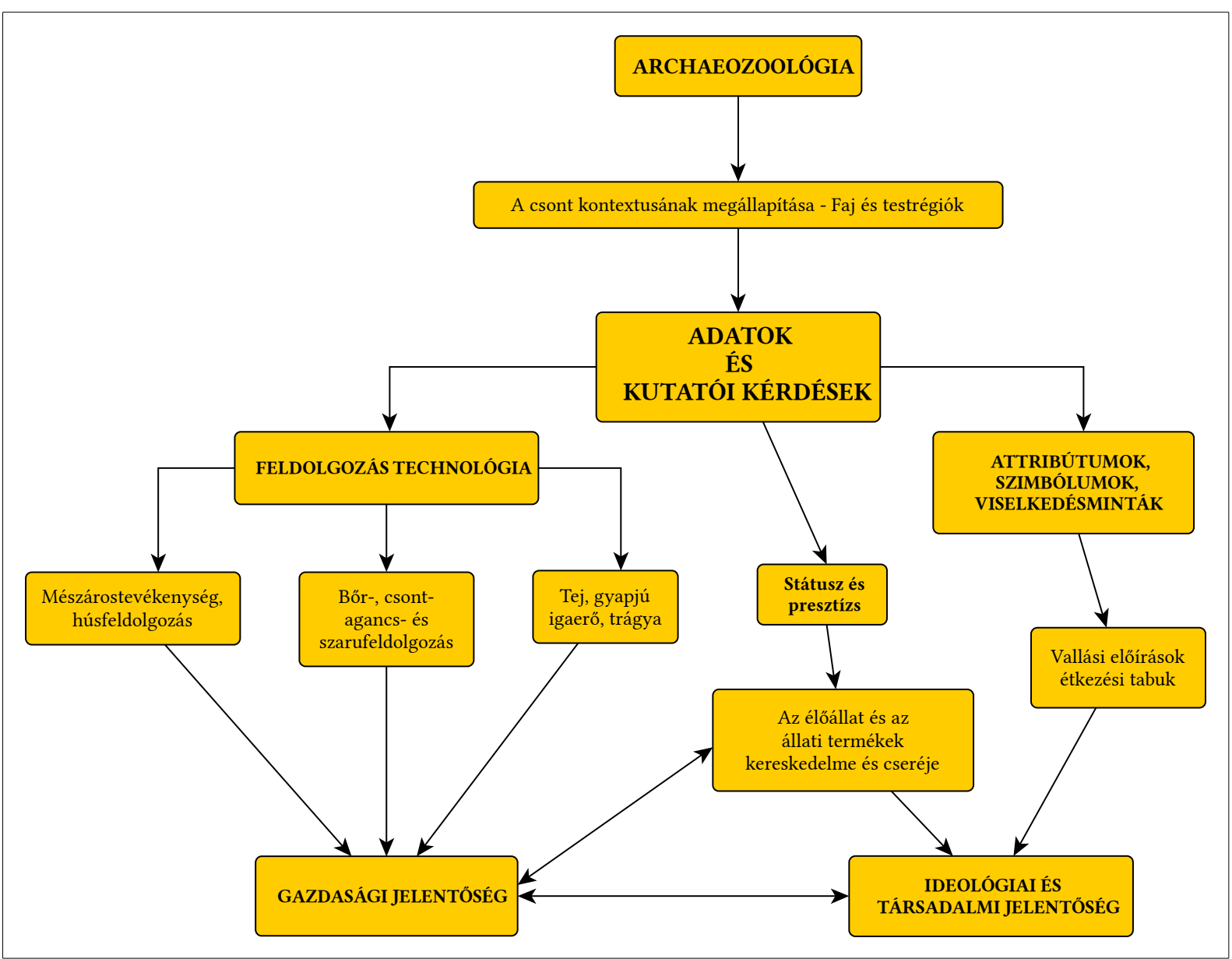

Fig. 9. Az állatcsontok kulturális jelentéseinek összefüggései. Relations between the cultural meanings of the animal bone finds (after CHOYKe - BARTOSIEwiCZ - LyublyANovics 2005).

Ahhoz, hogy magasabb szintű kulturális következtetést tudjunk az állatcsont leletek elsődleges biológiai és/vagy kulturális jellegű információiból levonni, fel kell használnunk mind a régészeti leletek osztályozási és értelmezési kategóriáit, mind a különböző kvantitatív módszerek (eloszlásvizsgálat, statisztikai elemzések) eredményeit, mind pedig az alfejezet elején megállapított axiómákat. Vissza kell tehát kanyarodnunk a régészet entitásaival foglalkozó alfejezethez.

Amennyiben követjük Clarke a régészet alapvető entitásait megállapító, a tárgyleletekre alkalmazott módszerét, abban az esetben ezeknek az entitásoknak megfeleltethető jelenségeket kell találnunk az állatcsontleletek esetében is. Problémát okozhat, hogy míg a tárgy leletek esetében csupán egyetlen értelmezési (t.i. kulturális) lehetőség adott, addig az állatcsontleletek alapvetően kétféle értelmezési lehetőséget kínálnak. Nem lehet tehát olyan könnyen begyömöszölni őket „Prokrusztész ágyába”. A megfeleltetés azonban korántsem 
lehetetlen azáltal, hogy már az elemzés legelején meghatározzuk az analízis célkitűzéseit, élesen elkülönítve a biológiai és a kulturális jellegű információkat. Ennek lehetőségét mutatja az alábbi táblázat:

\begin{tabular}{|c|c|c|}
\hline Entitás & Biológiai információ & Kulturális információ \\
\hline Attribútum & Állati maradvány & Faji bélyeg \\
\hline Tárgy & Csont & Csont \\
\hline Tárgytípus & Vázelem & Faj \\
\hline Leletcsoport & Váz/Vázrész & Több faj \\
\hline Kultúra & Faj/Fajpopuláció & Állattartási specifikáció \\
\hline Kulturális csoport & A település összes állata & Fajspecifikáció \\
\hline Technológiai komplexum & A település ökoszisztémája & Állattartók/Állattartás jellege \\
\hline
\end{tabular}

A biológiai jellegü információk esetében az egyes régészeti entitás kategóriák tulajdonképp magának az analízis felismerési, vagy inkább azonosítási kategóriáinak felelnek meg. Az attribútum megjelölése a legalapvetőbb szintet jelöli. Ez az állati maradvány. Ennek oka, hogy biológiai szempontból pusztán az állati maradvány, mint minőség megállapítása az elsődleges információ. Az állati maradványokra jellemző attribútum-készletekkel ellátott csont, vagy csonttöredék, mint tárgy meghatározása a második kategória. Forma és funkció alapján az egyes csontok, vagy csonttöredékek meghatározható vázelemekké minősülhetnek át, ezáltal alkotva típusokat. Biológiai szempontból az egy egyedhez tartozó vázrészletek, vagy vázak jelentenek olyan csoportot, amely kvalitatív és kvantitatív oldalról is mérhető, vagy értékelhető adatokat kínál. Az adott fajról ezáltal mind mennyiségi, mind minőségi információkat kaphatunk. Ezen a szinten a faj és a fajpopuláció kissé összemosódik.

Ebben a tekintetben talán szerencsésebb lenne e két szint szétválasztása, azonban akárcsak a régészet tudományában a paleoökológiai kutatások során is az egyén (állatok esetében inkább egyed) kutatása nem, vagy csak bizonyos keretek között lehetséges (Fig. 10).

A településen élő állatok összessége feltétel nélkül megfeleltethető egy kulturális csoportnak, hiszen az adott fajok (kultúrák) kapcsolatban álló csoportjának tekinthetőek. Maga a technológiai komplexum, vagyis a keretrendszer, amely ezeket az állatpopulációkat magába foglalja, létezésüknek teret ad, ám egyúttal szabályozza is őket: az a speciális ökoszisztéma, amely az emberi tevékenység hatására (állattartás) létrejött.

Kulturális szempontból az állatcsontleletek megfeleltetése a régészet egyes entitásainak, a biológiai szempontok értelmezésével - egészen a leletcsoport szintjéig - majdhogynem azonos. Ez abból a tényből fakad, hogy az állatcsont alapvetően biológiai jellegű információkat hordoz és ezen alapvető biológiai információk megállapítása után válik a kulturális információk megállapítására alkalmassá. Fontos azonban, hogy a kulturális jellegű információk felgyüjtésénél az analitikai szintek összevontak. 


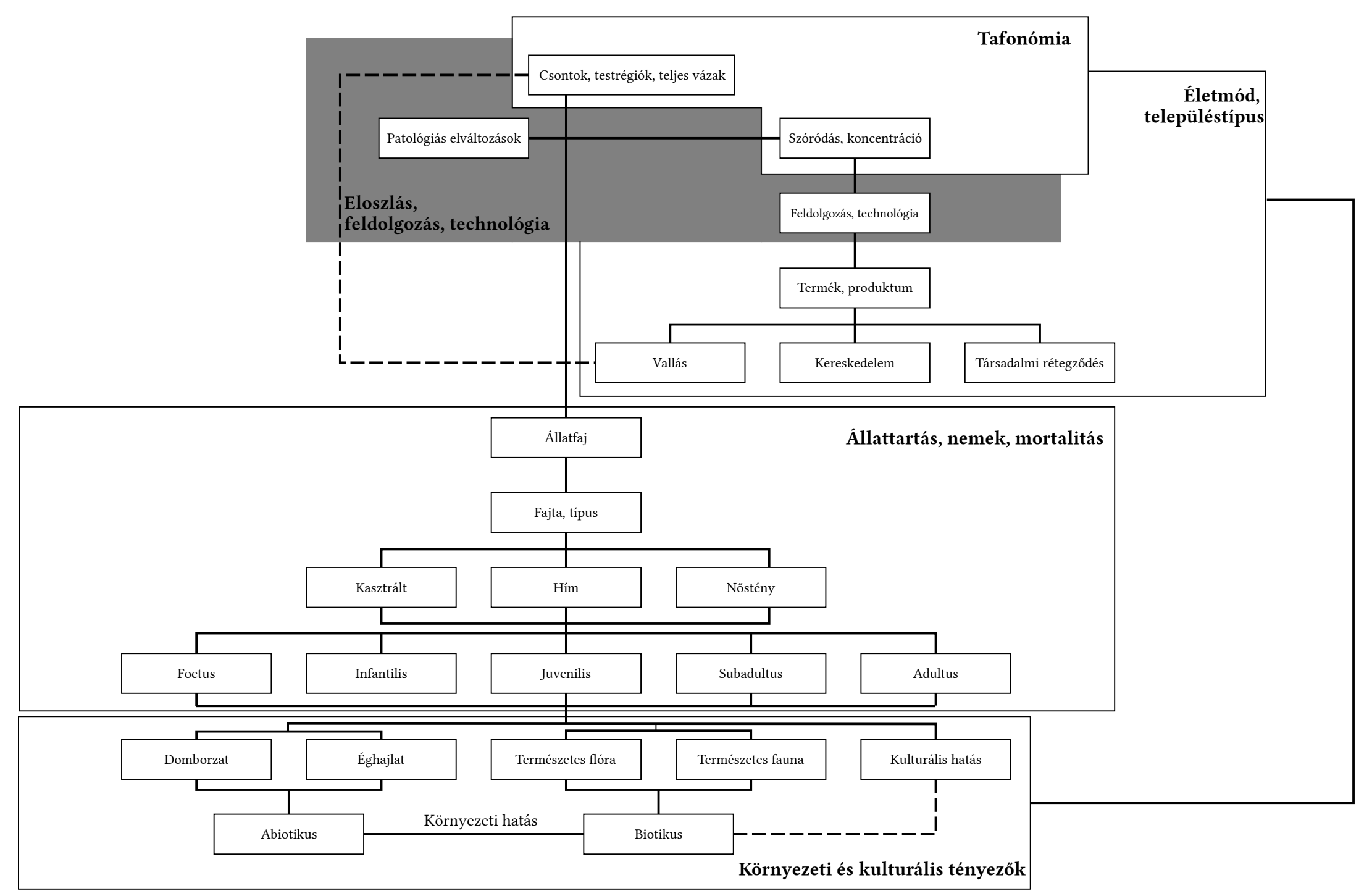

Fig. 10. A zooarchaeológiai adatok interpretációjának folyamatábrája.Flowchart of the interpretation of animal bone finds (after CsIPPÁN 2007). 
Ez az összevonás teszi lehetővé a kultúra, mint entitás szintjén a tényleges kulturális jelenségek vizsgálatát az állatcsontleleteken keresztül. Ezen kulturális jelenségek, már Bökönyi által is kulturálisan meghatározottnak mondott archaeozoológiai szempontból megfigyelhető formája az egykori közösség (kultúra) által tartott és/vagy vadászott házi- és vadállatok fajösszetétele. ${ }^{111} \mathrm{Az}$ állomány összetétele és formája alapvetően függ az azt hasznosító népességtől, jóllehet bizonyos tekintetben ökológiailag is meghatározott. Ennek a kulturális el(meg)határozásnak (t.i. hogy milyen állatot tartanak) egy nagyobb halmaza az egyes fajokhoz történő kötődés, illetve az egyes fajok meghatározó szerepe.

Etnológiai párhuzamok alapján ilyen jelenségnek tarthatjuk például a kenyai maasai-k szarvasmarha tartását is. Ez a típusú dominancia nem az adott faj kizárólagos tartását és más ha szonállatfajok teljes mellőzését jelenti, azonban a népesség létfenntartási stratégiája és gazdasága alapvetően erre az adott fajra épül.

Az entitások tekintetében a technológiai komplexum szintjét a létfenntartási stratégia legmeghatározóbb jellemzője jelenti. Ez pedig esetünkben az állattartás ténye, illetve annak jellege. A Kárpát-medencében nem ismerünk olyan régészeti népességet, amelyik ne fogyasztott volna húst, illetve amelyik a neolitikumtól kezdve ne tartott volna háziállatokat. ${ }^{112}$ Vadászó és gyűjtögető népességek esetében ez a vadászat jellegével, bizonyos fajok célzott vadászatával lehet azonos.

A puszta biológiai jellegű információkból tehát kulturális információk válhatnak azáltal, hogy célzott - a régészet által alkalmazott - kutatási struktúrába helyezzük őket, megfeleltetve azoknak az entitásfogalmaknak, amelyek ezen struktúrák alapját képezik. Mindezek alapján talán bizonyítottnak látszik, hogy az állatcsontleletek olyan többdimenziós információhordozó forráscsoportot képeznek, melynek elemzésén keresztül a kultúra számos részterülete is vizsgálható.

\section{Irodalom}

Ashby, W. R. 1972: Bevezetés a kibernetikába. Budapest.

Bartosiewicz, L. 1988: Biometrics at an Early Medieval butchering site in Hungary. In: Tate, E.A. Slater, J. O. (eds.): Science and Archaeology. British Archaeological Reports, British Series 196. Oxford, 361-367.

BARTosiewicz, L. 2006: Régenvolt háziállatok. Bevezetés a régészeti állattanba. Budapest.

Binford, L. R. 1962: Archaeology as Anthropology. American Antiquity 28, 217-225.

Binford, L. R. 1964: A consideration of archaeological research design. American Antiquity 29, 425-441.

BoAs, F. 1975: Népek, nyelvek, kultúrák. Budapest.

BöKÖNyI, S. 1968: Az állattartás fejlődése Közép- és Kelet-Európában. Agrártörténeti Szemle 10, 277-342.

Цалкин, В. И. 1960: Изменчивость метаподии и ее значение для изучения крупного рогатого скота древности. Бюлл. М. о-ва исп. природы. Отд. биологии 65.1, 100-126.

Childe, V. G. 1929: The Danube in Prehistory. Oxford.

112 Vadászó és gyűjtögető népességek esetében ez a vadászat jellegével, bizonyos fajok célzott vadászatával lehet azonos. 
Choyke, A. M. 1987: The exploitation of red deer in the Hungarian Bronze Age. Archaeozoologia 1, $109-116$.

Сноуке, A. M. 2009: Grandmother's Awl: Individual and Collective Memory through Material Culture. In: Barbiera, I. - Choyke, A. M. - Rasson, J. (eds.): Materializing Memory, Archaeological Material Culture and the Semantics of the Past. British Archaeological Reports, International Series 1977. Oxford, 21-40.

Clarke, D. L. 1968: Analytical Archaeology. London.

CsıppÁn, P. 2007: Ökológiai módszerek a régészetben. Archaeologiai Értesítő 132, 81-103.

CsippÁn, P. 2008: Az állatcsontok kulturális szokásokat jelző szerepe. Budapest Régiségei 41, 299-318.

DARóczi-SzABÓ, L. 2002: Animal bones as indicators of kosher food refuse from 14th century AD Buda, Hungary. In: O'Day, S. J. - Van Neer, W. - Ervynck, A. (eds.): Behaviour Behind Bones. The zooarchaeology of ritual, religion, status and identity. Proceedings of the 9th ICAZ Conference. Durham 2002, 252-261.

Descola, P. - Lenclud, G. - Severi, C. - Taylor, A.-C. 1994: A kulturális antropológia eszméi. Budapest.

von DEN Dreisch, A. 1976: A guide to the measurement of animal bones from archaeological sites. Peabody Museum Bulletins 1 . Harvard University.

Furholt, M. 2008: Culture History Behind Cultures: The Case of the Baden Culture. In: Furholt, M. - Szmyt, M. - Zastawny, A. (eds.): The Baden Complex and the Outside World. Proceedings of the 12th Annual Meeting of the EAA in Cracow, 19-24th September 2006. Bonn, 13-24.

Gamble, C. 2004: Archaeology: The Basics. London.

GeERTZ, C. 2001: Az értelmezés hatalma. Budapest.

GÉczy, B. 1984: Őslénytan. Budapest.

HodDER, I. 1982: Symbols in Action. Cambridge.

Hollós, M. 2000: Bevezetés a kulturális antropológiába. Szimbiózis 1995/5. Budapest.

Jefremov, J. A. 1940: Taphonomy: New branch of Paleontology. Pan-American Geologist 74.2, 81-93.

KossinA, G. 1926: Ursprung und Verbreitung der Germanen in vor- und frühgeschichtlicher Zeit. Berlin.

Lyman, R. L. 1994: Vertebrate Taphonomy. Cambridge.

Lyman, R. L. 2008: Quantitative Paleozoology. Cambridge.

Matolcsi, J. 1970: Historische Erforschung der Körpergrösse des Rindes auf Grund von ungarischen Knochenmaterial. Zeitschrift für Tierzüchtung und Züchtungsbiologie 87.2, 89-137.

Matolcsi, J. 1975: A háziállatok eredete. Budapest.

NoBis, G. 1954: Zur Kenntnis der ur- und frühgeschichtlichen Rinder Nord- und Mitteldeutschlands. Zeitschrift für Tierzüchtung und Züchtungsbiologie 63, 155-194.

Reitz, E. J. - Wing, E. R. 1999: Zooarcheology. Cambridge.

Renfrew, C. - BAhn, P. 1999: Régészet. Elmélet, módszer, gyakorlat. Budapest.

Shotwell, J. A. 1955: An approach to the paleoecology of mammals. Ecology 36, 327-337.

SikLósı, Zs. 2006: A régészeti kultúra fogalmának változása és az etnikai identitás azonosítása az ősrégészeti kutatásokban. Korall 24-25, 73-88. 
TYLor, E. B. 1997: A primitív kultúra. In: Bohannan, P. - Glazer, M. (eds.): Mérföldkövek a kulturális antropológiában. Panem, 108-130.

VAJDA, L. 1949: A néprajztudomány kultúrtörténeti iránya és a „bécsi iskola”. Ethnographia 60, $45-71$.

VöRös, I. 2003: Vadászott állatok. In: Visy, Zs. (ed.): Magyar régészet az ezredfordulón. Budapest, $56-60$.

Wissler, C. 1927: The Culture-area Concept in Social Anthropology. American Journal of Sociology 32.6, 881-891. 